\title{
Late Holocene lake-level and lake development signals in Lower Herring Lake, Michigan
}

\author{
Julie A. Wolin \\ Center for Great Lakes and Aquatic Sciences, University of Michigan, Ann Arbor, MI 48109, USA \\ Present address: Geobotany Division, Geological Survey of Denmark, Thoravej 8, Dk-2400 Copenhagen NV, \\ Denmark \\ e-mail: gb012@mmdgu.dgu.min.dk
}

Received 10 August 1993; accepted 22 June 1995

Key words: diatoms, grain-size analysis, lake-level changes, Lake Michigan, paleolimnology

\begin{abstract}
Paleolimnological investigations of a marginal lake in the Lake Michigan basin revealed signals of long-term lakelevel changes primarily controlled by climatic forces. Multiple analyses identified concurrent signals in sediment chemistry, grain size, and the microfossil record. Coarse-grained sediments, benthic diatoms, and nutrient response species increased as lake levels rose or fell. Finer sediments and higher percentages of taxa associated with stable thermocline conditions occurred during high-lake periods. Sedimentary evidence revealed corresponding strong high-lake signals $c .2500-2200,1800-1500,1170-730$, and 500-280 BP. Low-lake periods occurred $c$. 1500-1170 and 700-500 B.P. An additional signal of lake-level decline was apparent beginning c. $280 \mathrm{BP}$ but was interrupted by anthropogenic effects. Evidence of extreme low-lake levels (c. 1400-1300 BP), and signals for a medieval warming period (1030-910 BP) and the Maunder minimum (370-325 BP) indicate occurrence of short-lived dry climatic conditions.
\end{abstract}

\section{Introduction}

Regional information on climatic change is important for fine tuning predictions of global climate change and its effects on specific areas. Because their surface area is large relative to the total drainage basin, the Laurentian Great Lakes are particularly sensitive to climatic changes. Signals of short-term climatic fluctuations (on the order of 11-20 year cycles) are visible from the historic record (National Oceanic and Atmospheric Administration, NOAA, 1992) and it has been suggested that long-term signals (500-600 year periodicities) are also present (Larsen, 1985a). Larsen's conclusions, however, were based on discontinuous stratigraphic evidence and have been subject to alternate interpretation (Bishop, 1990). The purpose of this study was to investigate the paleolimnological record for evidence of long-term changes through analysis of multiple sedimentary parameters. Lake sediments should provide a record of such fluctuations, recording a continuum of lake-level change from high to low stages. Additionally, short-lived climatic events should also be recorded, signals that are generally missing from shoreline deposits such as those used by Larsen.

Although climate plays a driving force in Lake Michigan lake-level fluctuations, these signals are not readily evident in deep basin sediments. Due to its size, only large-scale changes are preserved, while more minor changes go undetected (Richardson, 1969). Additionally, sediments are not evenly distributed, but are confined to individual basins. Numerous marginal lakes are present around the Lake Michigan basin, however, and provide an excellent opportunity to investigate long-term lake-level fluctuations.

The Herring Lakes basin was once an embayment of pro-glacial Lake Algonquin (c. 11500 BP; Dorr \& Eschman, 1970). Lower Herring Lake was formed during post-Nipissing time (2000-2500 BP), when longshore wind and wave action created a baymouth bar. 
At present, the lake lies at the same elevation above sea level $(176.5 \mathrm{~m})$ as Lake Michigan and is connected via a small channel that flows $c .183 \mathrm{~m}$ through the baymouth bar (Fig. 1). A steep bottom slope along the western side of Lower Herring Lake inhibits sediment accumulation. Groundwater readily moves through this sand barrier equalizing lake-levels between Lower Herring Lake and Lake Michigan, even when the channel is closed. Lower Herring Lake thus mirrors lake-level fluctuations that occur in Lake Michigan, and because of its smaller size, provides more easily discernible signals in the sediments.

\section{Land use history}

One advantage of working on North American lakes is the relatively minor impact of human activities prior to European settlement. Paleolimnological investigations of lake-level change in European and Asian lakes are many times hindered by human impact in the lake basin (Okuda, 1984; Dearing \& Foster, 1986; Gaillard et al., 1991). In Lower Herring Lake, anthropogenic influences are confined to recent sediments, providing a good paleolimnological record of lake-level change below this point.

European impact on the Herring Lake basin began with deforestation c. AD 1845 (Glarum, 1983). A small settlement and lumbermill was established along Herring Creek in 1851 and operations continued until 1860. After a brief hiatus, the sawmill restarted in 1863 but ceased operation following a basin-wide forest fire in 1867. Another small settlement existed on the southern shore from 1890 until c. 1896. Since the early 1900's, Lower Herring Lake has primarily been used for recreational purposes. Approximately 150 cottages are present around the lake with a concentration of about 45 at the Herring Creek inlet. To varying extents, these cottages contribute nutrient loadings to the lake via septic systems and lawn fertilizers.

\section{Modern limnology}

Lower Herring Lake is a mesotrophic, hard water lake $(\mathrm{pH}=7.5-8.5)$ located in the northwestern part of Michigan's lower peninsula $\left(44^{\circ} 34.0^{\prime} \mathrm{N} ; 86^{\circ} 12.5^{\prime} \mathrm{W}\right)$. Historic water chemistry data, obtained from the Michigan Department of Natural Resources, indicate summer anoxic conditions existed at least as early as 1955. The lake is moderately deep $\left(Z_{\max }=23 \mathrm{~m}\right.$, 1989 ) with a surface $A=182$ ha and a $56.5 \mathrm{~km}^{2}$ drainage basin. Bottom profile soundings in 1989 indi- cated presence of a bench around the $6 \mathrm{~m}$ contour (Fig. 1) along the southeast shore of the lake.

The main axis of Lower Herring Lake lies northsouth. Prevailing winds across Lake Michigan come from the southwest in summer and northwest in winter. This exposes the lake to strong wind mixing forces. Lake Michigan's influence is also seen in air temperature moderation, creating longer cooling periods in fall and longer warming periods in spring. Ice cover typically lasts from December until mid-March, and windy conditions during spring and fall periods either increase ice break-up or delay ice formation, respectively. In warmer years, prolonged spring and/or fall mixing conditions exist. Early ice-out and late ice formation expose the lake surface to greater wind action. During lower water periods, thermocline stability would be more difficult to maintain due to wind induced turbulence.

Macrophyte distribution conducted by the Michigan DNR (Dept. Natural Resources) in 1955 reported some vegetation with greatest concentrations in the southeastern region of the lake. Little vegetation is present along the west shoreline where water depths increase rapidly. Dominant macrophyte genera reported were Najas, Potamogeton, and Scirpus, with dense patches of Chara in shallow water. Recent observations $(1985,1986$ and 1990) indicate Chara abundance appears confined to small patches scattered throughout shallow water areas.

\section{Methods}

\section{Coring}

Five sediment cores were taken along a transect (Fig. 1) using a modified Livingstone piston corer (Wright, $1967,1991)$ in February and September 1989. The transect was chosen along a moderately sloped edge of the basin in order to retrieve sediment cores which would span the transition from shallow to deep water (cf. Digerfeldt, 1986). The original intent of this study was to examine a series of cores along this transect for concurrent signals in sediment characteristics indicative of changing water levels. However, it was learned that the 12 and $9 \mathrm{~m}$ contours lie on a sandy slope with little to no sediment accumulation. Cores from the 3 and $6 \mathrm{~m}$ sites contained recent sand accumulations followed by intervals of sandy organic sediment, returning to sand. The $3.9-\mathrm{m}$ core discussed in this paper was obtained from $15.25 \mathrm{~m}$ water depth along 


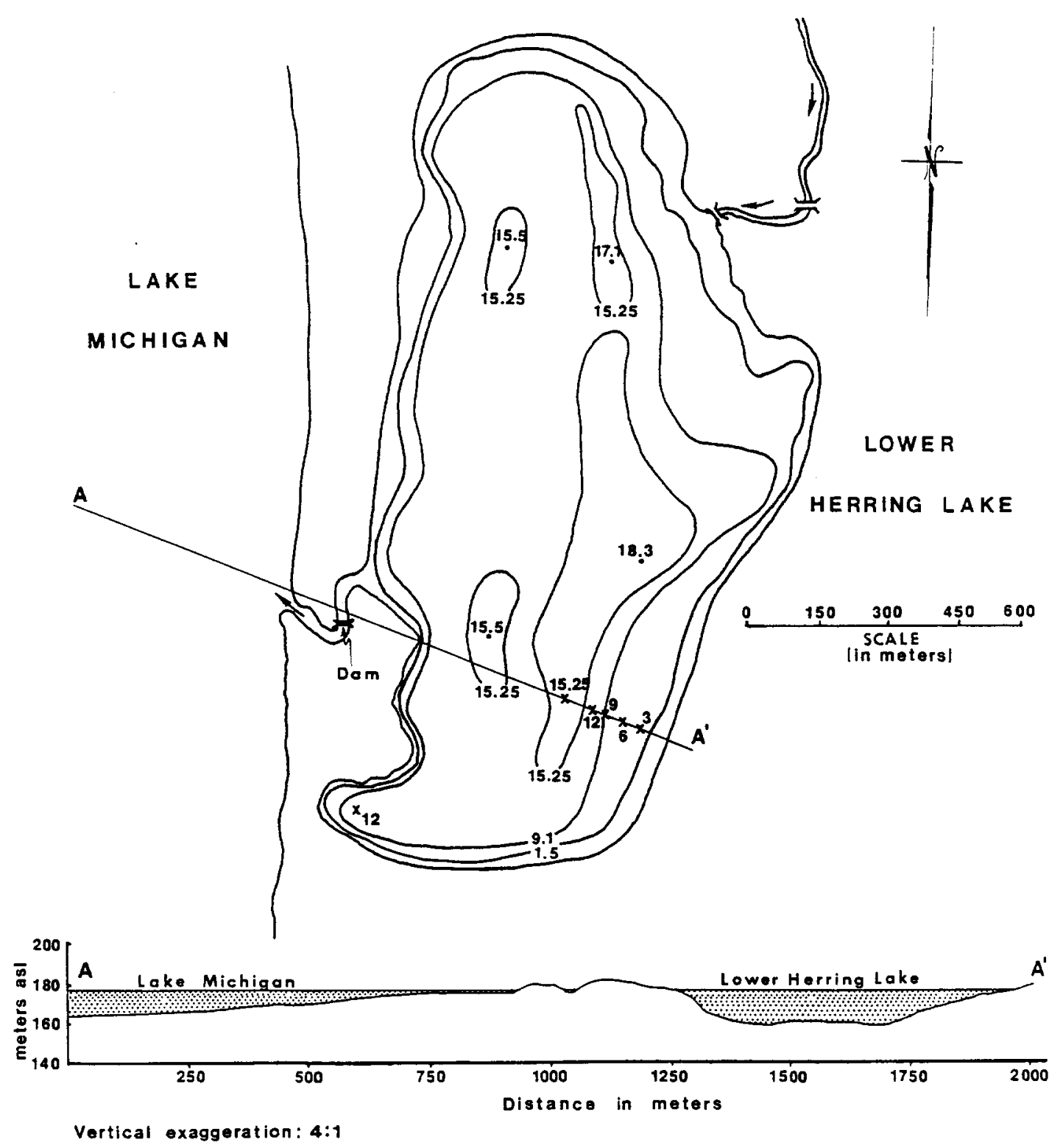

Fig. 1. Bathymetry of Lower Herring Lake (after Fisheries Research Board Michigan Lake Survey, 1955). Both Lower Herring Lake and Lake Michigan lie at the same elevation (176.5 $\mathrm{m}$ asl). The channel connecting the two lakes is visible along the west side of Lower Herring Lake.

the transect shown in Fig. 1. The first section was taken using a polycarbonate tube and extruded vertically to preserve the loosely compacted surficial sediment. This portion was sectioned in $1-\mathrm{cm}$ intervals in the field, stored in Whirl-pak bags, and refrigerated. The subsequent five sections were taken with an aluminum core barrel, extruded horizontally, wrapped in plastic and aluminum foil, and refrigerated. These sections were later subsampled in 1-cm intervals in the laboratory. An additional core $(122 \mathrm{~cm}$ in length) was taken from a $12 \mathrm{~m}$ depth at the southwestern end of the lake in June 1990 (Fig. 1). This core was sectioned in the field and stored as was the first section in the master core. In order to provide material for future study or for exchange with other investigators, portions of each core have been archived.

\section{Chronology}

The upper $40 \mathrm{~cm}$ of the master core were analyzed for ${ }^{137} \mathrm{Cs}$ and ${ }^{210} \mathrm{~Pb}$ to determine age and sediment accumulation rates for the past $100-150$ years. The surface 
section $(0-1 \mathrm{~cm})$ was not analyzed due to lack of material. Samples were sent to Dr Claire Schelske, Department of Fisheries and Aquaculture, University of Florida for dating. Measurements were made with a lowbackground gamma-counter (Appleby et al., 1986) using a well-type germanium detector (EG\&G Ortec) and a 4096-channel pulse-height analyzer. Sediment samples were pressed into polypropylene test tubes (Sarstedt, $14 \mathrm{~mm}$ O.D., $12 \mathrm{~mm}$ I.D.) to a nominal depth of $30 \mathrm{~mm}$ and weighed. A layer of epoxy was then placed over the sample to seal it and ensure equilibrium between ${ }^{226} \mathrm{Ra}$ and ${ }^{214} \mathrm{Bi}$, which was used to measure supported ${ }^{210} \mathrm{~Pb}$ activity. Total ${ }^{210} \mathrm{~Pb}$ activity was obtained from the $46.5 \mathrm{keV}$ gamma peak and supported ${ }^{210} \mathrm{~Pb}$ activity was obtained from the $609 \mathrm{keV}$ peak of ${ }^{214} \mathrm{Bi}$. Unsupported ${ }^{210} \mathrm{~Pb}$ activity was determined from the difference between total and supported ${ }^{210} \mathrm{~Pb}$ activity. Ages were calculated from unsupported ${ }^{210} \mathrm{~Pb}$ activity using the constant rate of supply (c.r.s.) model (Appleby \& Oldfield, 1983).

Plant material found embedded in the sediment matrix was extracted and later sent to the NSF Accelerator Facility for Radioisotope Analysis at the University of Arizona for ${ }^{14} \mathrm{C}$ dating. Sample 1 (AA-6739) was composed of leaf material found in the first core section at $83-84 \mathrm{~cm}$. This sample was sectioned in the field, frozen and freeze-dried immediately upon return to the laboratory. Samples 2, 3 and 4 (AA-6740, AA6741 , AA-6742, respectively) were taken from wood fragments embedded in the second and third sections of the core, at 145-146, 205-206, and $249-253 \mathrm{~cm}$, respectively. These samples had been refrigerated for five months prior to sectioning and were then stored in Whirl-pak bags and refrigerated for about a year before being dated. Sample 5 (AA-6743) was composed of conifer needle material found in the fifth section at $340-342 \mathrm{~cm}$. This sample had been refrigerated for five months prior to sectioning and then freezedried. An additional sample (AA-6744) taken from core LHL-40-90 was also dated. This core was sectioned in the field and freeze-dried immediately upon return to the laboratory. The sample was taken from $96 \mathrm{~cm}$ below the sediment surface and was identified as aquatic macrophyte material. The calibrated dates are shown in Table 1.

\section{Geochemistry}

Sediment composition was characterized using losson-ignition techniques (Dean, 1974). Weighed subsamples (100-200 mg) were taken at each 1-cm level and oven dried to remove any excess water. Organic matter and carbonate content were determined by calculating weight loss at 550 and $1000^{\circ} \mathrm{C}$, respectively.

Biogenic silica analyses were based on methods developed by DeMaster $(1979,1981)$. Analyses were run on all samples. Subsamples of 20-25 mg dry wt sediment were digested in $40 \mathrm{ml}$ of $1 \% \mathrm{Na}_{2} \mathrm{CO}_{3}$ solution at $85^{\circ} \mathrm{C}$ in poly-propylene bottles. One $\mathrm{ml}$ aliquots were removed after 2,3 , and $4 \mathrm{~h}$ and analyzed for dissolved silica by the heteropoly blue method (Davis \& Simmons, 1979) using an AutoAnalyzer II. Biogenic silica concentrations for each sample were determined using a locally developed program. This program fits a least squares regression line to extracted silica concentration vs time to correct for mineral interference $\left(\mathrm{R}^{2}=0.99-0.88\right)$. The extrapolated intercept, at time zero, was taken as the biogenic silica concentration of the original sample. This technique relies on the difference between rapid dissolution of biogenic silica and the slower rate of dissolution from other silicate minerals within the sample (Krausse et al., 1983). Regression results for the upper portion of the core showed little or no mineral contribution from clay silicates due to high organic content of the sediments. For these samples, concentrations were determined from an average of the three extractions. Standard deviations for these determinations were $\pm 0.7 \%$. The lower portion of the core contained a greater percentage of clay minerals, therefore biogenic silica values for these samples were determined using the regression and extrapolation method described above.

\section{Grain-size analysis}

Well-mixed subsamples were weighed (100-400 mg) for each level and digested in a $1 \% \mathrm{Na}_{2} \mathrm{CO}_{3}$ solution at $85{ }^{\circ} \mathrm{C}$ for $1 \mathrm{~h}$ to dissolve biogenic silica components. Samples were rinsed with distilled water and sieved through $63 \mu \mathrm{m}$ and $38 \mu \mathrm{m}$ screens to separate the sand and coarse to medium silt fractions, respectively. These fractions were dried and weighed. Sediments in the depositional regions of a lake are predominantly composed of grains in the silt and clay size fractions $(<16 \mu \mathrm{m})$ (Håkanson \& Jansson, 1983). In order to determine changes occurring in this principal portion of the sediments, the remaining fraction $(<38 \mu \mathrm{m})$ was analyzed for grain-size distribution using a 256-channel Coulter Counter particle-size analyzer. Results are expressed as median grain sizes in phi units, $\phi_{50}$ of Folk (1974), where $\phi=-\log _{2}$ D and D 
Table 1. Calibrated radiocarbon dates (Pearson and Stuiver 1986)

\begin{tabular}{|c|c|c|c|c|c|}
\hline Depth in core & Lab \# & Material & Date & Calibrated BP & Calibrated date \\
\hline \multicolumn{6}{|l|}{ LHL-50-89: } \\
\hline $83-84 \mathrm{~cm}$ & AA-6739 & leaves & $530 \pm 55$ y BP & 579 cal BP & $1410 \mathrm{AD}$ \\
\hline $145-146 \mathrm{~cm}$ & AA- 6740 & wood & $245 \pm 55$ у ВР & 339 cal BP & $1650 \mathrm{AD}$ \\
\hline $205-206 \mathrm{~cm}$ & AA-6741 & wood & $290 \pm 55$ y BP & 349 cal BP & $1640 \mathrm{AD}$ \\
\hline $249-253 \mathrm{~cm}$ & AA- 6742 & wood & $535 \pm 55$ y BP & $581 \mathrm{cal} \mathrm{BP}$ & $1408 \mathrm{AD}$ \\
\hline $340-342 \mathrm{~cm}$ & AA- 6743 & conifer needles & $3435 \pm 60$ y $\mathrm{BP}$ & $3734 \mathrm{cal} \mathrm{BP}$ & $\begin{array}{l}1765-1700 \mathrm{BC} \\
(1745)\end{array}$ \\
\hline \multicolumn{6}{|l|}{ LHL-40-90: } \\
\hline $96 \mathrm{~cm}$ & AA- 6744 & aquatic plant stem & $1910 \pm 65$ y BP & $1892 \mathrm{cal} \mathrm{BP}$ & $125-70 \mathrm{AD}$ \\
\hline
\end{tabular}

Table 2. Taxa used in cluster analysis

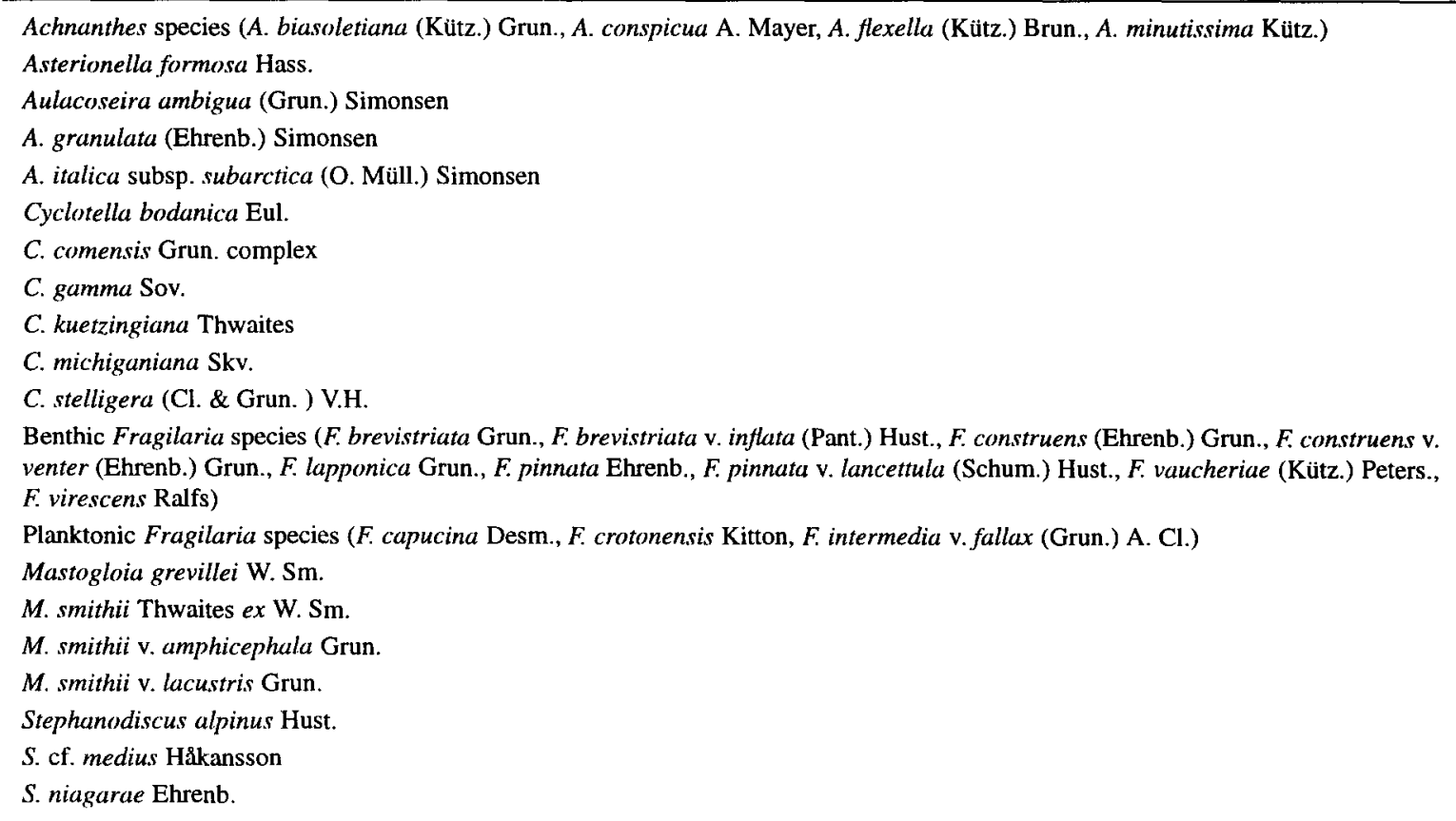

is the diameter of the particle in mm. Because preliminary analyses determined that particles in the silt and clay size fraction were predominantly $<2 \mu \mathrm{m}$, only the $50 \mu \mathrm{m}$ Coulter Counter tube was used. Samples were prepared by sieving through the $38 \mu \mathrm{m}$ screen. The $50 \mu \mathrm{m}$ tube analyzes particles in the size range of $9.97 \phi(1 \mu \mathrm{m})$ to $4.96 \phi,(32.08 \mu \mathrm{m})$ and samples are precise to $\pm 0.03 \phi$.

\section{Microfossil analysis}

Sediment material from the master core (LHL-50-89, $15.25 \mathrm{~m}$ depth) was used for microfossil analysis. Siliceous microfossils were subsampled using the biogenic silica profile as a guide. Samples were taken at $1 \mathrm{~cm}$ intervals from $0-12 \mathrm{~cm}$ and $2-\mathrm{cm}$ intervals from $12-40 \mathrm{~cm}$. Based on ${ }^{210} \mathrm{~Pb}$ dating, this section represents the most recent history of Lower Herring Lake following European settlement. The remaining portion 
of the core was subsampled at 5-cm intervals. Additional samples were taken when large changes in the biogenic silica profile fell between these intervals.

Subsamples of freeze-dried material were weighed and placed in $\mathrm{H}_{2} \mathrm{O}_{2}$ overnight, then heated to boiling. A small amount of potassium dichromate was then added to complete oxidation of the material (van der Werff, 1955). After rinsing repeatedly with distilled water to remove the potassium dichromate, approximately $10 \mathrm{ml}$ of $10 \% \mathrm{HCl}$ was added to remove carbonates. Samples were again rinsed to remove excess acid, then dried onto coverslips in Battarbee (1973) trays and mounted in Hyrax ${ }^{\circledR}$ following Patrick \& Reimer (1966).

Slides were enumerated following the procedure developed by Glover (1982). All recognizable algal remains (whole diatom valves and fragments, chrysophyte cysts and scales), carbon fragments, sponge spicules and phytoliths were recorded. Chrysophycean cysts were identified by morphotype and crossreferenced with plates or micrographs from the literature (Nygaard, 1956; Carney \& Sandgren, 1983; Sandgren \& Carney, 1983; Duff \& Smol, 1988). A minimum of 500 valves were counted for each sample with the exception of the last $1 \mathrm{~m}$. Because algal microfossils were scarce in these sections, a minimum of 500 valves or 4 coverslip transects were counted, whichever came first. Surface samples contained high numbers of a small Cyclotella species. When counts of 500 valves were used for enumeration, the presence of other species were masked by the overwhelming dominance of this taxon. To alleviate this problem and expose as much of the assemblage as possible, enumeration was continued until a minimum of 500 valves of a sub-dominant taxon (Aulacoseira) was counted. Samples were enumerated using a Leitz Ortholux microscope equipped with fluorite oil immersion objectives providing c. $1200 \times$ magnification and $1.30+$ numerical aperture.

Diatom and chrysophyte raw data were encoded, mathematically 'reconstituted', and processed using a local data base management system (FIDO) for quantitative and qualitative analysis. Plotting and statistical analysis of diatom and chrysophyte data were performed using the University of Michigan Computing Center's operating system (MTS) and the MIDAS statistical package (Fox \& Guire, 1980). Diatom relative abundance data was analyzed using an agglomerate cluster analysis employing Euclidean distance and the single-linkage average-distance method (Carney,
1982). Major taxa (Table 2) were chosen based on their presence in at least $50 \%$ of the samples in each section and representing at least $1 \%$ of the population. Clusters were run for the entire core to identify major assemblage divisions.

\section{Results}

\section{Chronology}

${ }^{137} \mathrm{Cs}$ and ${ }^{210} \mathrm{~Pb}$ profiles and sediment accumulation rates are presented in Figs. 2a,b,c. Historical records place deforestation around AD 1845 (Glarum, 1983), whereas ${ }^{210} \mathrm{~Pb}$ estimates from the sediment record place this event at 1834 . Because of the increasing uncertainty of ${ }^{210} \mathrm{~Pb}$ dating beyond 100 years, sedimentary signals of deforestation (increases in sand, coarse silt and carbon fragments) were used as a stratigraphic marker to date this level $(35 \mathrm{~cm})$. This date was then used to calculate sedimentation rates. Mean sedimentation rate since $1845(35 \mathrm{~cm})$ was calculated to be $0.0538 \mathrm{~g} \mathrm{~cm}^{-2} \mathrm{yr}^{-1}$. Sediment accumulation (Fig. 2c) is gradual between 1845 and 1866 then increases from 1866 to 1929 . A broad peak occurs between 1929 and 1944 followed by a rapid increase in accumulation after 1957.

Radiocarbon dates were inconsistent in the middle portion of the core. All three samples were obtained from wood chips. Sample 3 (AA-6741) was found near the surface of the third section and could have been transported there during coring. Samples 2 and 4 (AA-6740 and AA-6742) were taken from inside the sediment matrix and did not appear to have been transported down the side of the core tube. All three dates yield unreasonably high sedimentation rates $(0.56 \mathrm{~cm}$ $\mathrm{yr}^{-1}, 0.83 \mathrm{~cm} \mathrm{yr}^{-1}$, and $0.49 \mathrm{~cm} \mathrm{yr}^{-1}$ ) compared with recent post-settlement rates of $0.24 \mathrm{~cm} \mathrm{yr}^{-1}$ (calculated from ${ }^{210} \mathrm{~Pb}$ dates). Surface sedimentation rates should be greater than the lower portion of the core due to compaction. A lower sedimentation rate of $0.05 \mathrm{~cm}$ $\mathrm{yr}^{-1}$ was also estimated from ${ }^{14} \mathrm{C}$ sample 6 (AA-6744) dated from core LHL-40B-90. Due to the questionable nature of samples $2-4$, it was decided that only radiocarbon dates from samples 1 and 5 (AA-6739 and AA6743) would be used to determine time sequencing. All dates reported are calibrated according to Pearson \& Stuiver (1986). Because isolation of Lower Herring Lake would result in changes in sedimentation, rates were calculated separately for pre- and post-isolation sections of the core $(395-240 \mathrm{~cm}$ and $218-35 \mathrm{~cm}$, 


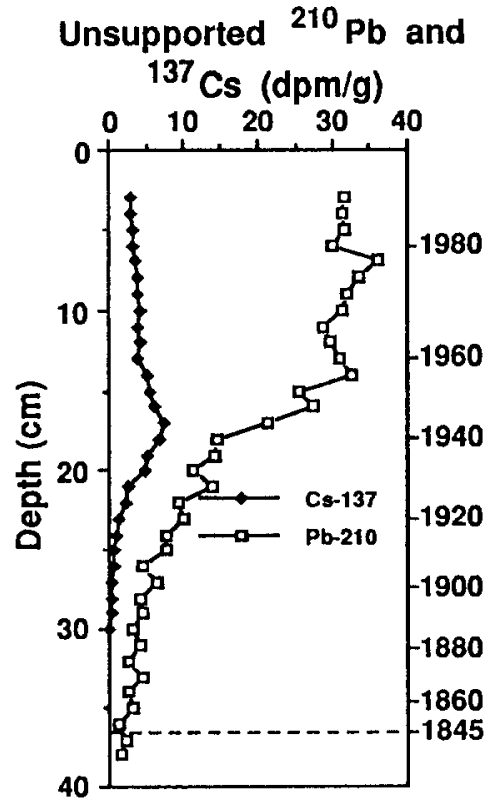

a.
Age (before 1989)

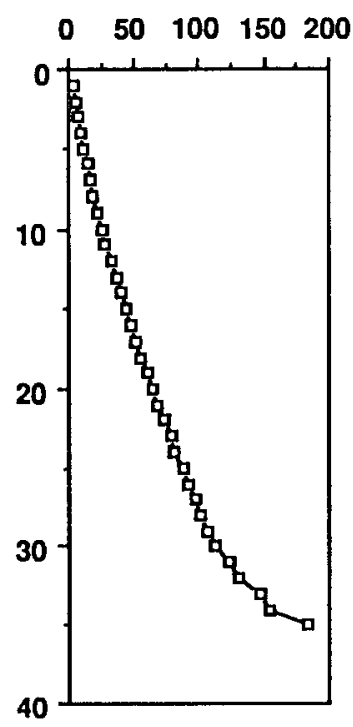

b.

\section{Sediment Accumulation} (mg/cm2/yr)

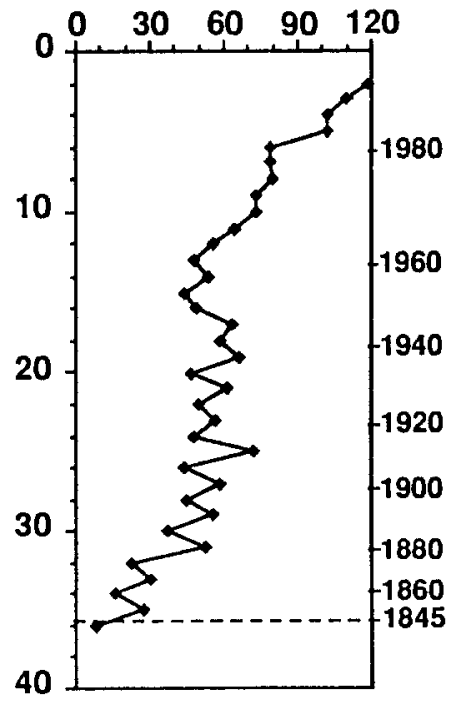

c.

Fig. 2. Unsupported ${ }^{210} \mathrm{~Pb}$ and ${ }^{137} \mathrm{Cs}$ stratigraphy (a), age-depth relationship (b), and sediment accumulation rate based on ${ }^{210} \mathrm{~Pb}$ dating (c).

respectively). Sedimentation rates for the middle portion of the core $(218-35 \mathrm{~cm})$ were $0.11 \mathrm{~cm} \mathrm{yr}^{-1}$. This was calculated using the calibrated ${ }^{14} \mathrm{C}$ date at $83 \mathrm{~cm}$ (579 BP) and timing of the deforestation signal $(35 \mathrm{~cm}$, $144 \mathrm{BP})$. Estimates used for sequencing in the lower portion of the core $(395-240 \mathrm{~cm})$, prior to isolation, were $0.063 \mathrm{~cm} \mathrm{yr}^{-1}$. This rate was calculated from the calibrated ${ }^{14} \mathrm{C}$ date at $341 \mathrm{~cm}(3743 \mathrm{BP})$ and an estimated date at $218 \mathrm{~cm}(1800 \mathrm{BP})$ derived from the post-isolation sedimentation rate.

\section{Lithology}

Visual inspection of the master core ( $15.25 \mathrm{~m}$ site) revealed sediments primarily composed of gyttja with several sand layers and increasing clay content in the lowest portion. Results of field descriptions and laboratory observations were combined to create the lithology presented in Fig. 3. During sectioning and preparation for biogenic silica analysis, regions containing fibrous-like material or coarser grains and shell were also noted.

\section{Geochemistry}

Loss-on-ignition data were smoothed using a threepoint running average for clearer presentation of the data. Original profiles without smoothing may be obtained from the author. Organic matter was lowest (c. 5-10\%) in the bottom sediments from 388 to $245 \mathrm{~cm}$ (Fig. 3). A dramatic change in sediment composition occurs around $235-240 \mathrm{~cm}$, where organic content increases from 10 to $15 \%$ and increases again between 215 and $190 \mathrm{~cm}$ to $c$. $20 \%$. Organic content remains between $20-25 \%$ in the upper sediments (190$50 \mathrm{~cm}$ ). The upper $50 \mathrm{~cm}$ of the core contain slightly lower amounts of organic matter (c. 20\%), although an increase occurs in the top $5 \mathrm{~cm}$.

Carbonate content is variable but reach highest amounts $(25 \%)$ in the lower portion of the core between 390 and $245 \mathrm{~cm}$. A decline occurs at $245 \mathrm{~cm}$ (from 20 to $13 \%$ ) followed by an increase, peaking around $225 \mathrm{~cm}$ (c. 20\%). The carbonate fraction is lower between $218-187 \mathrm{~cm}(c .15 \%), 148-102 \mathrm{~cm}(11-15 \%)$, and $77-43 \mathrm{~cm}$ (c. 17\%) with increases occurring between $187-148 \mathrm{~cm} \mathrm{(c.} \mathrm{20 \% )} \mathrm{and} \mathrm{102-78} \mathrm{cm} \mathrm{(c.} \mathrm{18-20 \% ).}$ A sharp decline occurs $c .36 \mathrm{~cm}$, followed by an increase between $24-12 \mathrm{~cm}$ to $c$. $23 \%$. Carbonate content declines rapidly above $12 \mathrm{~cm}$.

Biogenic silica results (Fig. 3) were smoothed using a three-point running average. Lowest amounts occur in the bottom of the core (1-5 wt\%) with slight increases between $362-350$ and $330-315 \mathrm{~cm}$. Biogenic silica increases to $c$. $10 \%$ between $265-211 \mathrm{~cm}$. Sections above $211 \mathrm{~cm}$ contain the highest amounts (25$35 \mathrm{wt} \%$ ). Major decreases in wt\% occur at 180-170 


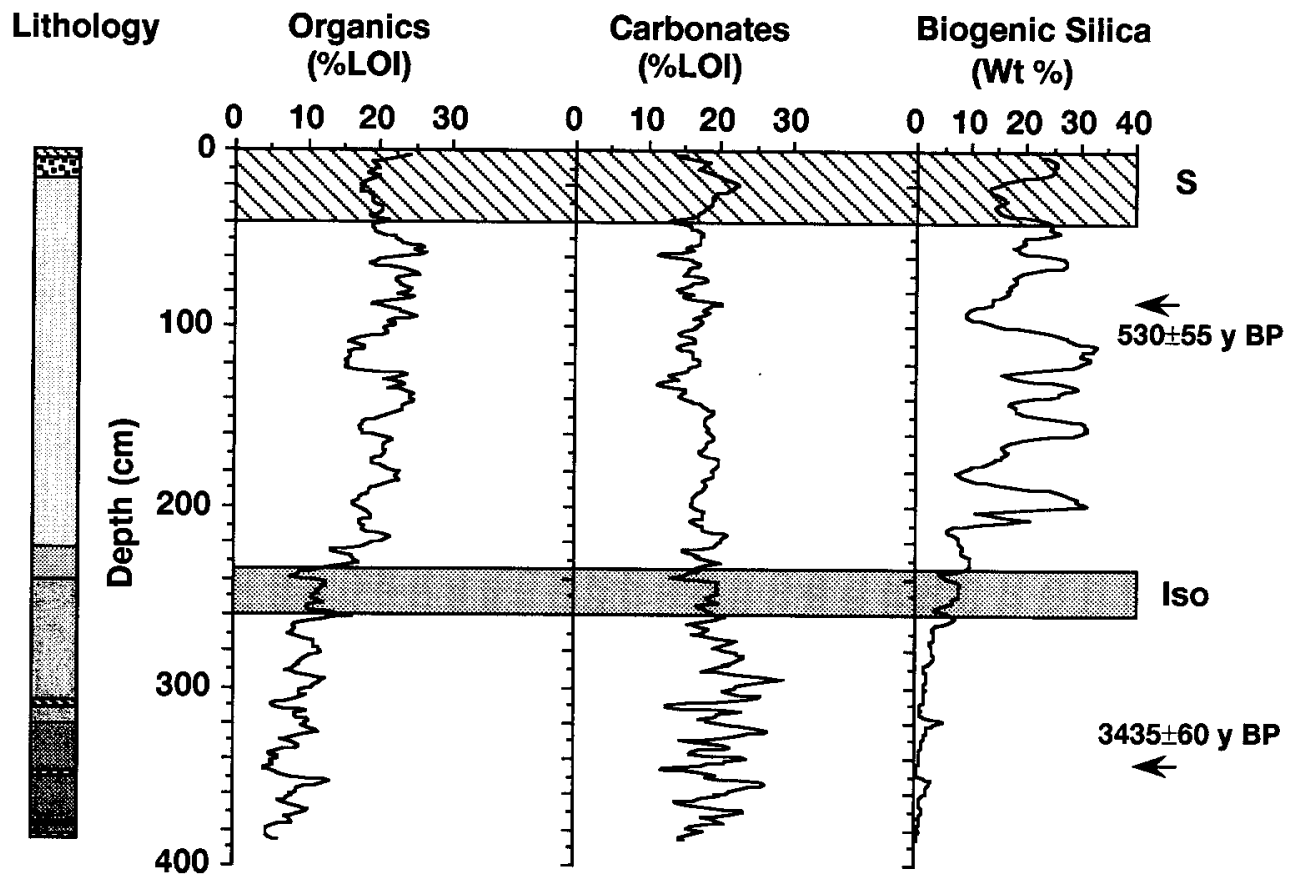

Fig. 3. Lithology and geochemical profiles for Lower Herring Lake core. ISO=isolation, $\mathrm{S}=$ post-settlement. A flocculent surface layer (light diagonal) is followed by brown sediment (confetti). The remainder of the core was composed of gyttja (shaded region) grading into clay gyttja below $220 \mathrm{~cm}$ (darker shadings) and interspersed with sandy gyttja (dark diagonal).

and $95-90 \mathrm{~cm}$, with less dramatic decreases at 155$145,140-130,55-48,36-30$, and $23-18 \mathrm{~cm}$. A rapid increase in the biogenic silica component occurs in surface sediments between $18-12 \mathrm{~cm}$ and remains high up to $4 \mathrm{~cm}$, declining to the surface.

\section{Grain size}

Size analysis of mineral components is shown in Fig. 4. All data were smoothed using a three-point running average. Silt and clay particles $(<38 \mu \mathrm{m})$ comprise $75-90 \%$ of the mineral fraction, coarse silt $(38-63 \mu \mathrm{m})$ accounts for $2-20 \%$, and sand $(>63 \mu \mathrm{m})$ accounts for $10-60 \%$ in the lower portion and $2-10 \%$ in the upper portion of the core. Greater than $95 \%$ of particles in the fine-grained fraction $(<38 \mu \mathrm{m})$ were in the clay size fraction $(<2 \mu \mathrm{m})$.

The sand fraction (Fig. 4) is highest between 388$245 \mathrm{~cm}$ and declines rapidly between $245-218 \mathrm{~cm}$. Sediments below $c .235 \mathrm{~cm}$ are dominated by coarse grains, whereas sand grains in the upper portion of the core are very fine. Although sand content remains below $10 \%$ in the upper sediments, slight increases occur between $218-198,187-160,102-71$ and $50-$ $40 \mathrm{~cm}$. Sand content is lowest in surface samples.

The 38-63 $\mu \mathrm{m}$ fraction fluctuated throughout the core ranging from 10 to $20 \%$ of the total sediment composition (Fig. 4). Increased amounts occurred at $235,215,130-120,60$, and $36 \mathrm{~cm}$ with the largest portion (35\%) at c. $17 \mathrm{~cm}$, in the surface sediments.

Phi $50\left(\phi_{50}\right)$ values for the $<38 \mu \mathrm{m}$ sediment fraction are plotted in Fig. 5. High phi values indicate fine particles and low values represent coarser particle distributions. While these data are influenced by the amount of coarse-grained material $(>38 \mu \mathrm{m})$, particlesize distributions provide a separate measurement of sedimentary changes occurring in the fine-grained fraction $(<38 \mu \mathrm{m})$.

Phi 50 distributions in lower sections of the core $(388-240 \mathrm{~cm})$ exhibit repeated fluctuations with coarser grains predominant between $350-330 \mathrm{~cm}$ and $305-$ $285 \mathrm{~cm}$. An influx of coarse particles is visible between 240 and $235 \mathrm{~cm}$ followed by an increase in finer particles. Above $218 \mathrm{~cm}$ another major influx of coarse particles occurs. In the upper portion of the core (218$36 \mathrm{~cm}$ ), coarser grained sediment influxes are present at 176 and $102 \mathrm{~cm}$ and other minor increases through- 


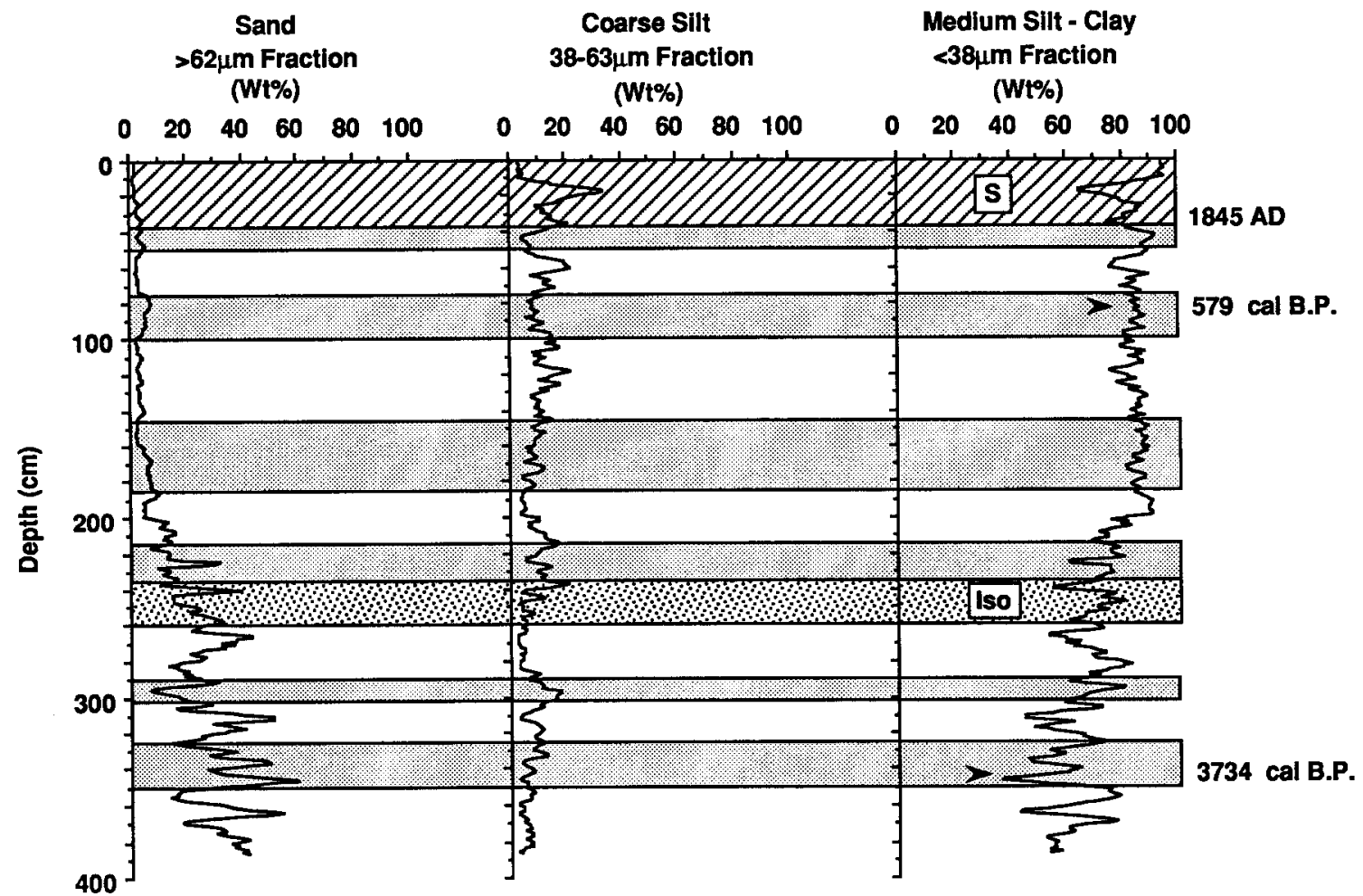

Fig. 4. Grain-size analysis of the Lower Herring Lake core. Shaded areas correspond to low-lake levels, unshaded areas correspond to high-lake periods. Other regions correspond to those in Fig. 3 geochemical profiles.

out. Overall, particle size is finer (higher phi values) than previous regions with coarser grain-sizes between $102-36 \mathrm{~cm}$. Grain-size distributions become much finer above $36 \mathrm{~cm}$ with the exception of an influx of coarse particles c. $20 \mathrm{~cm}$ (Fig. 5).

\section{Microfossil analysis}

Absolute and relative abundance data for major microfossil groups are shown in Fig. 6. A total of 473 taxonomic entities were identified including 380 diatom and 93 chrysophyte taxa (including cyst morphotypes). Microfossil numbers are low in the bottom portion of the core $(390-237 \mathrm{~cm})$, remain relatively constant between 237 and $20 \mathrm{~cm}$, then increases dramatically above $20 \mathrm{~cm}$ with a slight decline in the top $4 \mathrm{~cm}$. Chrysophycean cysts are a dominant component of the microfossil assemblage in the lowest section of the core. They decline in importance between 270 and $237 \mathrm{~cm}$ and remain a minor portion of the assemblage throughout the rest of the core. Relative abundances of diatom species are lowest between 390 and $275 \mathrm{~cm}$.
They increase in importance above $275 \mathrm{~cm}$ and remain the dominant microfossil component of the core.

Highest percentages of benthic and epiphytic diatoms occur below $237 \mathrm{~cm}$ (Fig. 7). Periodic increases in importance of these forms occur between 237 and $50 \mathrm{~cm}$. Planktonic forms fluctuate between high and low relative abundances in lower sediments increasing in importance up to $237 \mathrm{~cm}$. Above $237 \mathrm{~cm}$ planktonic forms dominate, comprising 75-90\% of the assemblage.

Relative abundances of Cyclotella species are shown in Fig. 8. Cyclotella comensis is present only in samples above $50 \mathrm{~cm}$ and becomes the dominant taxon above $18 \mathrm{~cm}$. Cyclotella bodanica is present throughout the core reaching greatest importance in the middle portion between $c .300$ and $36 \mathrm{~cm}$, then declining towards the surface. Cyclotella gamma is present, but of minor importance throughout the core and is rarely present above $20 \mathrm{~cm}$. Cyclotella kuetzingiana and C. michiganiana exhibit periodic increases and decreases in relative abundance. Both are present throughout the core with $C$. kuetzingiana decreasing in importance above $100 \mathrm{~cm}$. Cyclotella michiganiana 


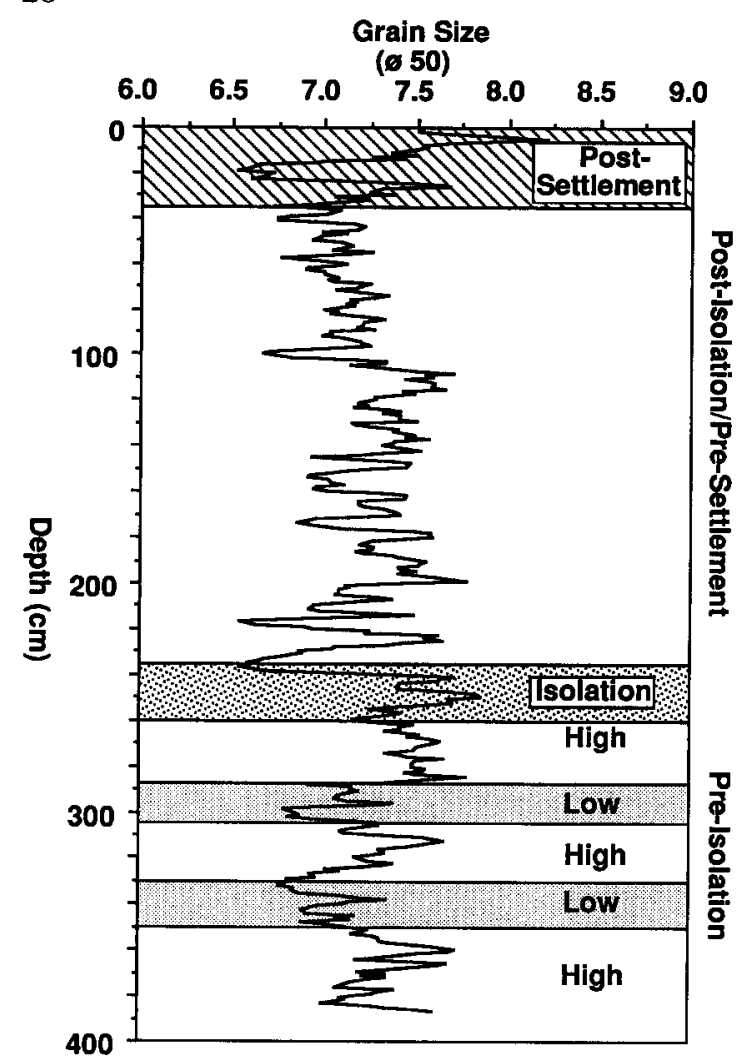

Fig. 5. Lake-level signals present in grain-size distribution of the Lower Herring Lake core. Shaded areas correspond to low-lake levels, unshaded areas correspond to high-lake periods.

increases above $70 \mathrm{~cm}$ and reaches highest percentages between $34-16 \mathrm{~cm}$ before declining to the surface. Cyclotella stelligera is present sporadically throughout the core with increased relative abundances at 120,60, and $16 \mathrm{~cm}$, and in surface samples $(8-4 \mathrm{~cm})$.

Relative abundance profiles of benthic and planktonic Fragilaria species, Aulacoseira ambigua and A. granulata are shown in Fig. 9. Benthic Fragilaria exhibit variable relative abundance in the lowest portion of the core $(390-237 \mathrm{~cm})$, remain between $2-4 \%$ from 237 to $60 \mathrm{~cm}$ with peak percentages at 142 and $50 \mathrm{~cm}$, and increase to $c .5 \%$ above $40 \mathrm{~cm}$. Planktonic Fragilaria species are low with sporadic distributions between 390 and $40 \mathrm{~cm}$. Above $40 \mathrm{~cm}$ percentages increase, reaching highest values between $20-8 \mathrm{~cm}$, declining between $8-4 \mathrm{~cm}$, and increasing at the surface. Aulacoseira ambigua is the primary representative of the genus in this core. Relative abundances are lower and somewhat variable between $390-237 \mathrm{~cm}$, then increase and remain high from $237-20 \mathrm{~cm}$ before declining toward the surface. Aulacoseira granulata profiles are similar to those of A. ambigua, but appear to exhibit slight increases in percent abundance between $150-60 \mathrm{~cm}$.

Absolute and relative abundance profiles of three major Stephanodiscus species are shown in Fig. 10. Stephanodiscus alpinus and $S$. cf. medius exhibit similar patterns of periodic increases and decreases throughout the core. Stephanodiscus niagarae is a more important component of assemblages between 390 and $237 \mathrm{~cm}$. It is present at relative abundances of $10-15 \%$ between 237 and $40 \mathrm{~cm}$, declines from 40 to $18 \mathrm{~cm}$ and is only a minor component above $18 \mathrm{~cm}$.

Cluster analysis was used to summarize changes in microfossil assemblages for all samples (Fig. 11). Results identified four major clusters, five small cluster groups, and four samples which form distant clusters. These latter four samples $(342,317,120$ and $18 \mathrm{~cm}$ ) represent periods of major assemblage changes and, in more recent sediments, indicate major basin disturbances. Cluster analysis indicates these samples show little affiliation with other assemblages in the core. The five small cluster groups represent samples from region $\mathrm{D}$ and are composed primarily of benthic taxa. Three samples from the upper sediments $(95,60$, and $45 \mathrm{~cm})$ also cluster with these groups, and represent samples from region $C$ that appear to be associated with basin disturbances. The earliest cluster (region D) includes samples from 390-275 cm (4500$2680 \mathrm{BP}$ ). This association is dominated by chrysophycean taxa and contains highest concentrations of benthic and epiphytic taxa. Region $C$ includes samples from 270-32 cm (2680-125 BP) and is dominated by planktonic diatom species. Assemblages begin to reflect anthropogenic influences in region B (20$30 \mathrm{~cm}$, AD 1882-1929). Major assemblage shifts begin to occur in this section of the core, and there is an increase in species tolerant of a wide range of nutrient conditions (eurytopic forms). Two samples from the lower portion of the core $(350$ and $261 \mathrm{~cm}$ ) are present between regions $\mathrm{A}$ and $\mathrm{B}$. These samples contain higher abundances in taxa that respond to nutrient influxes (i.e. Asterionella formosa, Cyclotella stelligera and Fragilaria crotonensis). The sample at $18 \mathrm{~cm}$, (late 1930's) clusters separately and represents a transition in microfossil assemblages from an indigenous flora, present throughout the lake's existence, to a new assemblage dominated by small planktonic Cyclotella species. Region A (16-0 cm, 1944-present) represents this altered flora. Human influence in the basin has created a change in the flora even greater than that which occurred as the lake became isolated. Assem- 


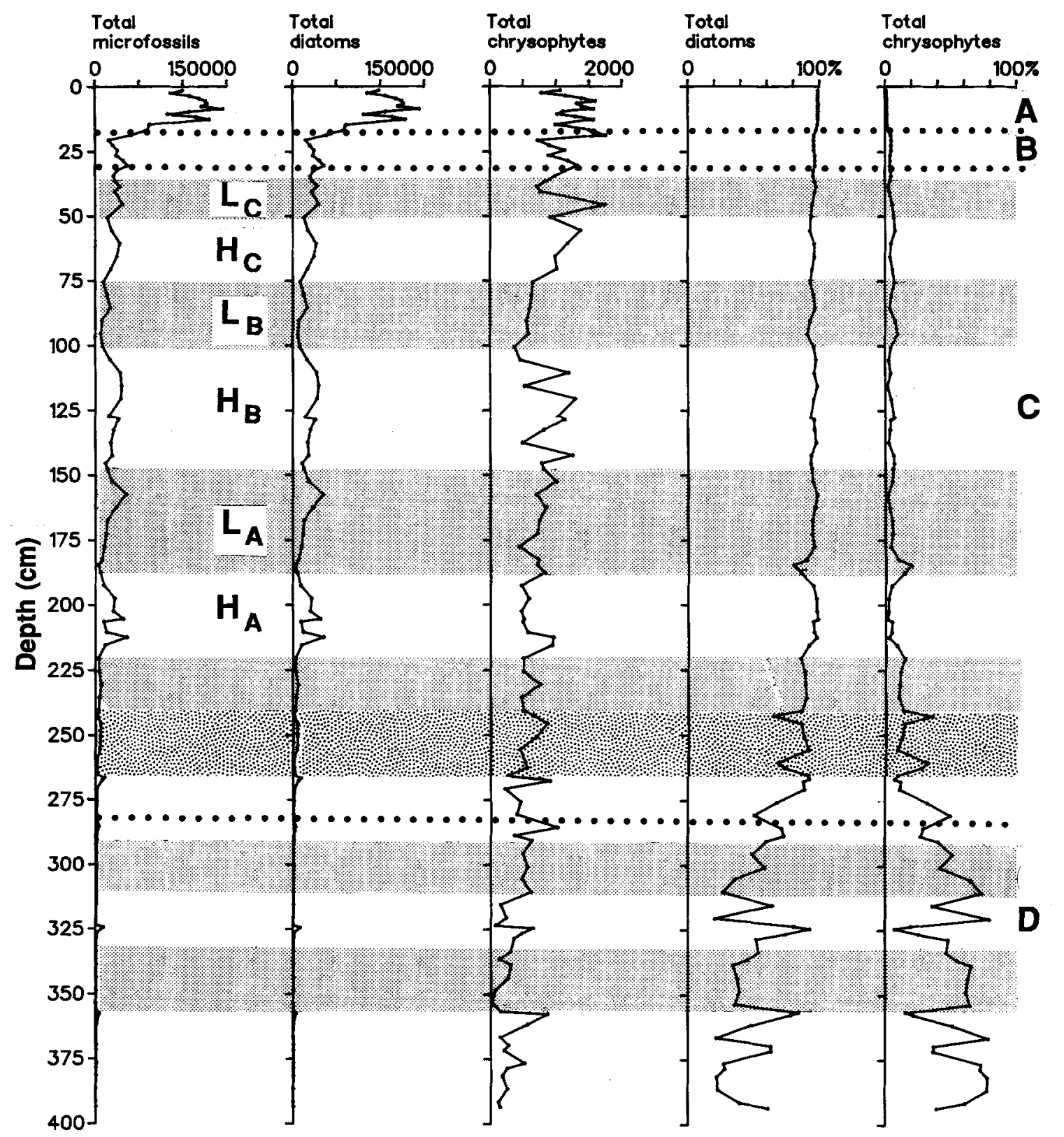

Fig. 6. Relative abundance (\%) and concentration (valves or cysts $\times 10^{3} \mathrm{mg}^{-1} \mathrm{dry}$ wt sediment) of major siliceous microfossil groups in Lower Herring Lake sediments. Regions (A-D) correspond to those of cluster analysis for the entire core. Shaded areas correspond to low-lake level periods and post-isolation lake levels are designated $\left(\mathrm{H}_{A}-\mathrm{L}_{C}\right)$. Coarse shading represents lake isolation period.

blages in this region have no previous analogue in the fossil record of Lower Herring Lake's history.

\section{Discussion}

Paleolimnological investigations of Lower Herring Lake sediments revealed signals of long-term lakelevel changes in the Lake Michigan basin which, because of their relatively recent nature (c. $4000 \mathrm{BP}$ to present), were primarily controlled by climate rather 


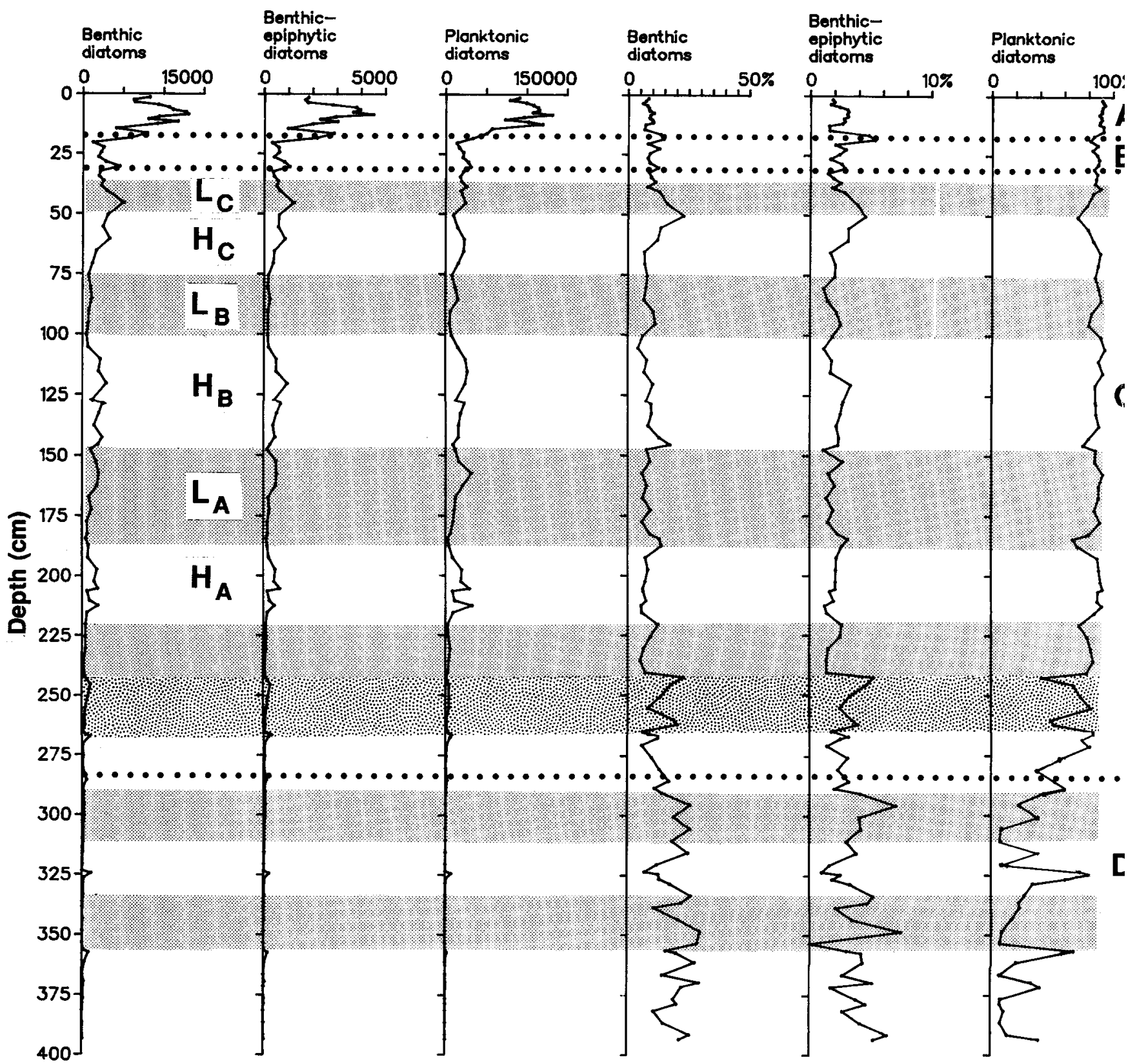

Fig. 7. Relative abundance (\%) and concentration (valves $\times 10^{3} \mathrm{mg}^{-1}$ dry wt sediment) of diatom habitat groups. Marked regions correspond to those defined in Fig. 6.

than glacial-tectonic forces. Lower Herring Lake provided a continuous sedimentary record of these fluctuations. Multiple analyses of sediment chemistry, grainsize, and the microfossil record (diatoms, chrysophytes, carbon fragments and phytoliths) were used to identify concurrent signals of lake-level change. These signals were then placed in a time frame based on ${ }^{210} \mathrm{~Pb}$ and ${ }^{14} \mathrm{C}$ radiometric dating techniques. Development of Lower Herring Lake from an embayment of ancestral Lake Michigan to an enclosed lake system is also recorded, as well as the impact of recent human settlement. A summary diagram of the paleolimnological information obtained from Lower Herring Lake is shown in Fig. 12. 


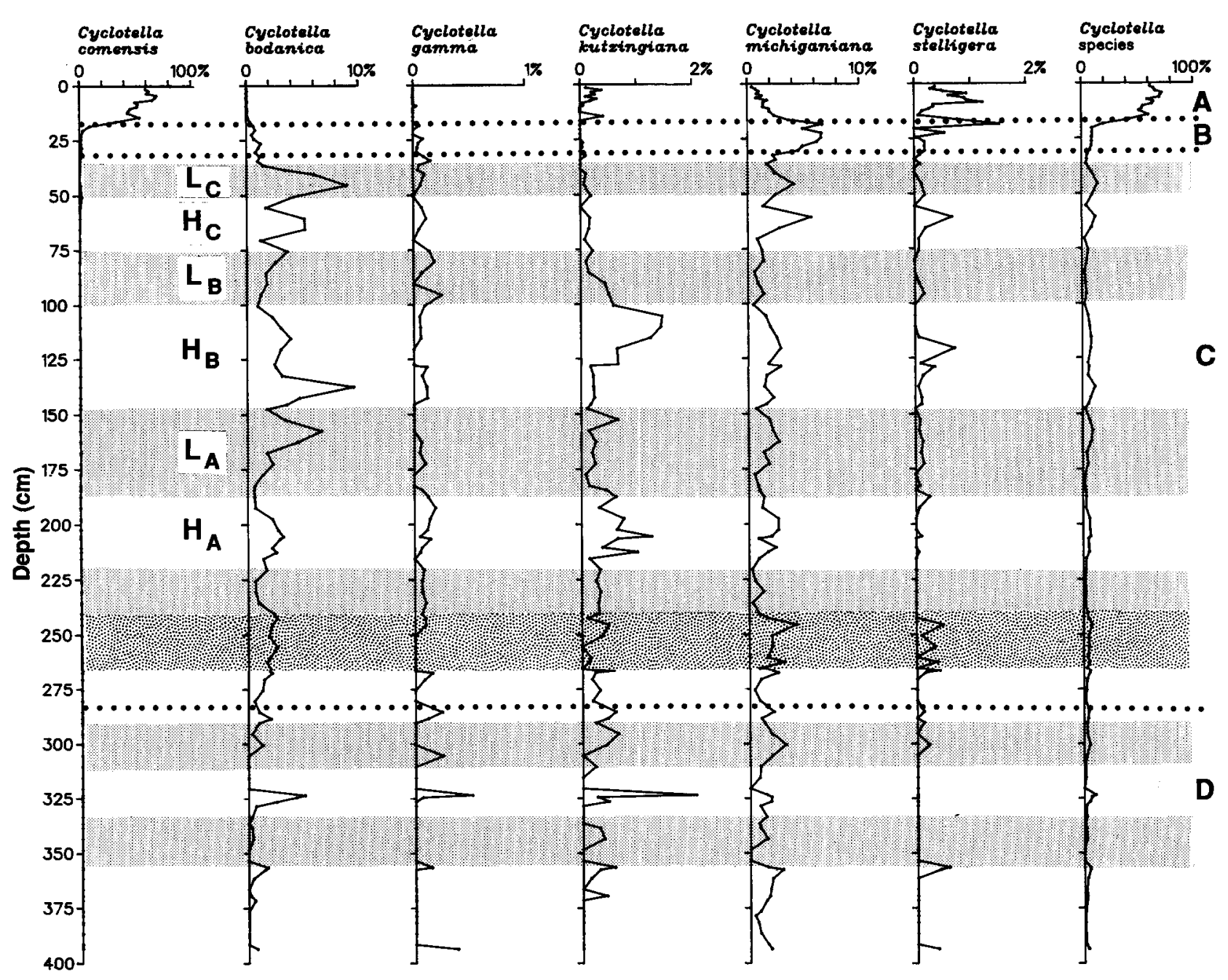

Fig. 8. Relative abundance (\%) of Cyclotella species in Lower Herring Lake sediments. Marked regions correspond to those defined in Fig. 6.

\section{Lake development and anthropogenic signals}

One of the strongest sedimentary signals present was the isolation of Lower Herring Lake from the Lake Michigan basin and its development as a marginal lake. Sediment analyses revealed four major regions in the core which have been defined as follows: (1) a pre-isolation period (c. $395-240 \mathrm{~cm}$ ); (2) final isolation period (c. $240-218 \mathrm{~cm}$ ); (3) post-isolation/pre- settlement period (c. 218-36 cm); and (4) the postsettlement period $(36-0 \mathrm{~cm})$. Since processes within each region differ, they will be discussed separately.

\section{Climatically induced lake-level signals}

Superimposed upon lake development and anthropogenic signals in Lower Herring Lake were those 


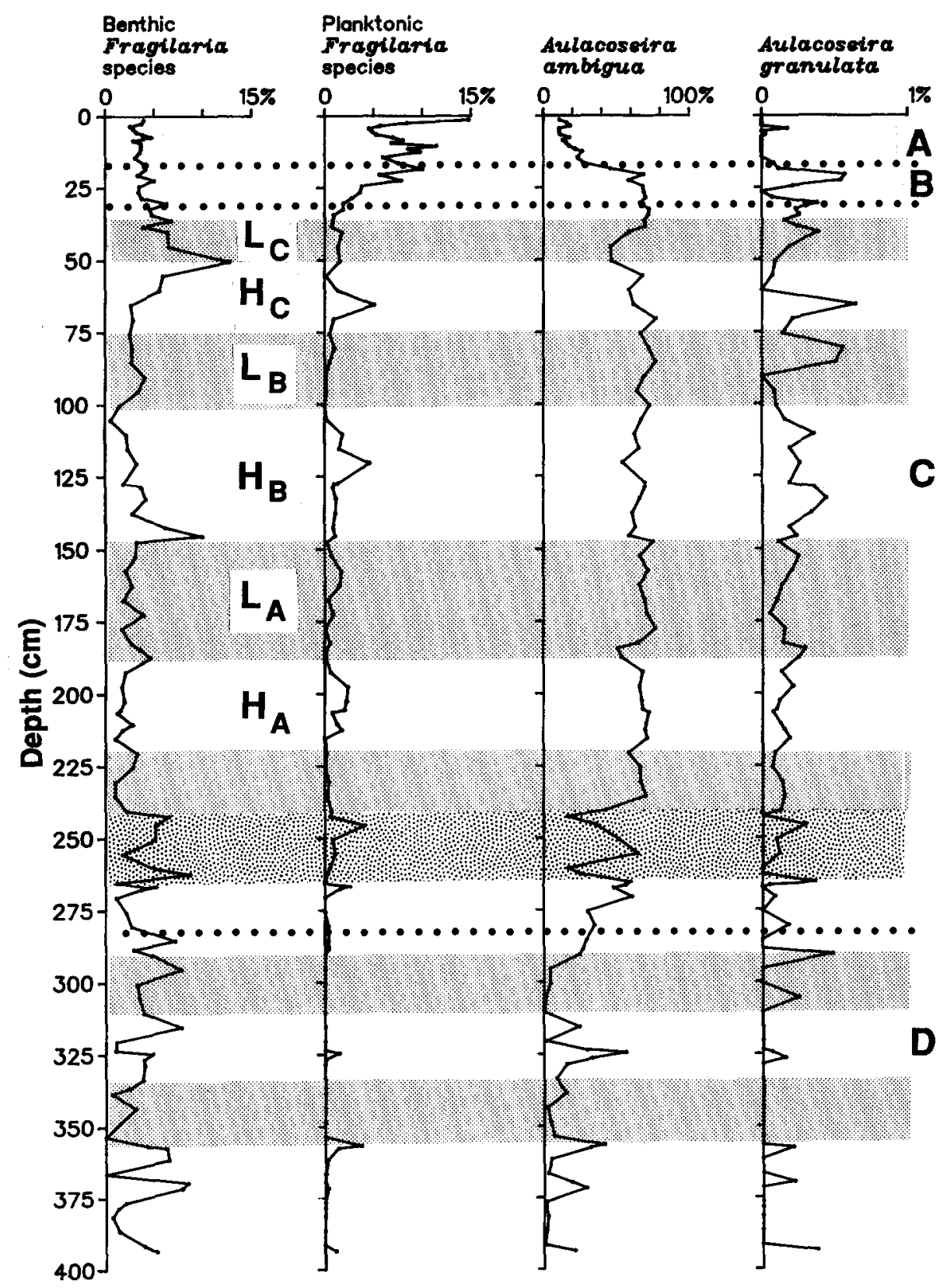

Fig. 9. Relative abundance (\%) of Fragilaria and Aulacoseira species in Lower Herring Lake sediments. Marked regions correspond to those defined in Fig. 6.

of lake-level change. Initial evidence for water-level fluctuations was found in the fine particle distribution of the sediments. Digerfeldt (1986) has shown that as lake levels fall, coarse near-shore sediments (sands) are carried further out into the lake basin and that during high-lake periods, fine sediments (silts and clays) are deposited closer into shore. These same processes are reflected within the fine sediments. Average grain-size $\left(\phi_{50}\right)$ distributions are coarser during low-lake periods, becoming finer during high-lake stands. Fine particle grain-size analysis has been used by several investigators for various climatic and basin disturbance inferences (Warwick, 1980; Yamamoto, 1984). 


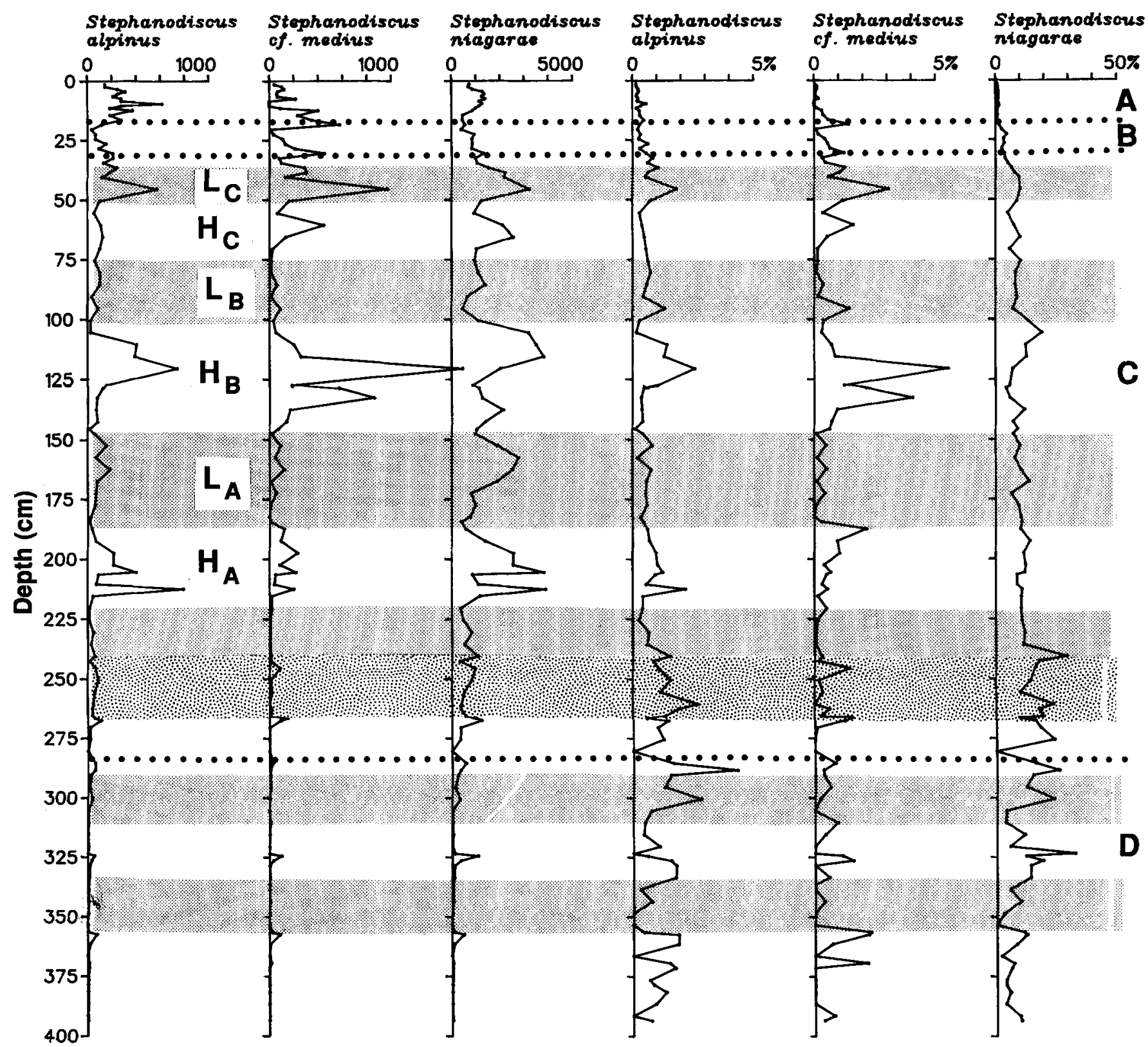

Fig. 10. Relative abundance (\%) and concentration (valves $\times 10^{3} \mathrm{mg}^{-1}$ dry wt sediment) of Stephanodiscus species in Lower Herring Lake sediments. Marked regions correspond to those defined in Fig. 6.

Additional evidence was also obtained from the carbonate, organic matter and biogenic silica fractions. Northern lower Michigan waters are rich in dissolved carbonates. Increased precipitation of $\mathrm{CaCO}_{3}$ commonly occurs as a result of warmer temperatures and increased primary productivity by algal populations and/or macrophytes, conditions more prevalent during low-water periods. Lower sedimentary carbonates would be expected during periods of higher water levels and/or lower water temperature. The amount of detrital carbonate in the sediments was not identified by loss-on-ignition data, however contribution from this fraction was assumed to be constant. Increases in organic matter would be expected as lake levels decline 


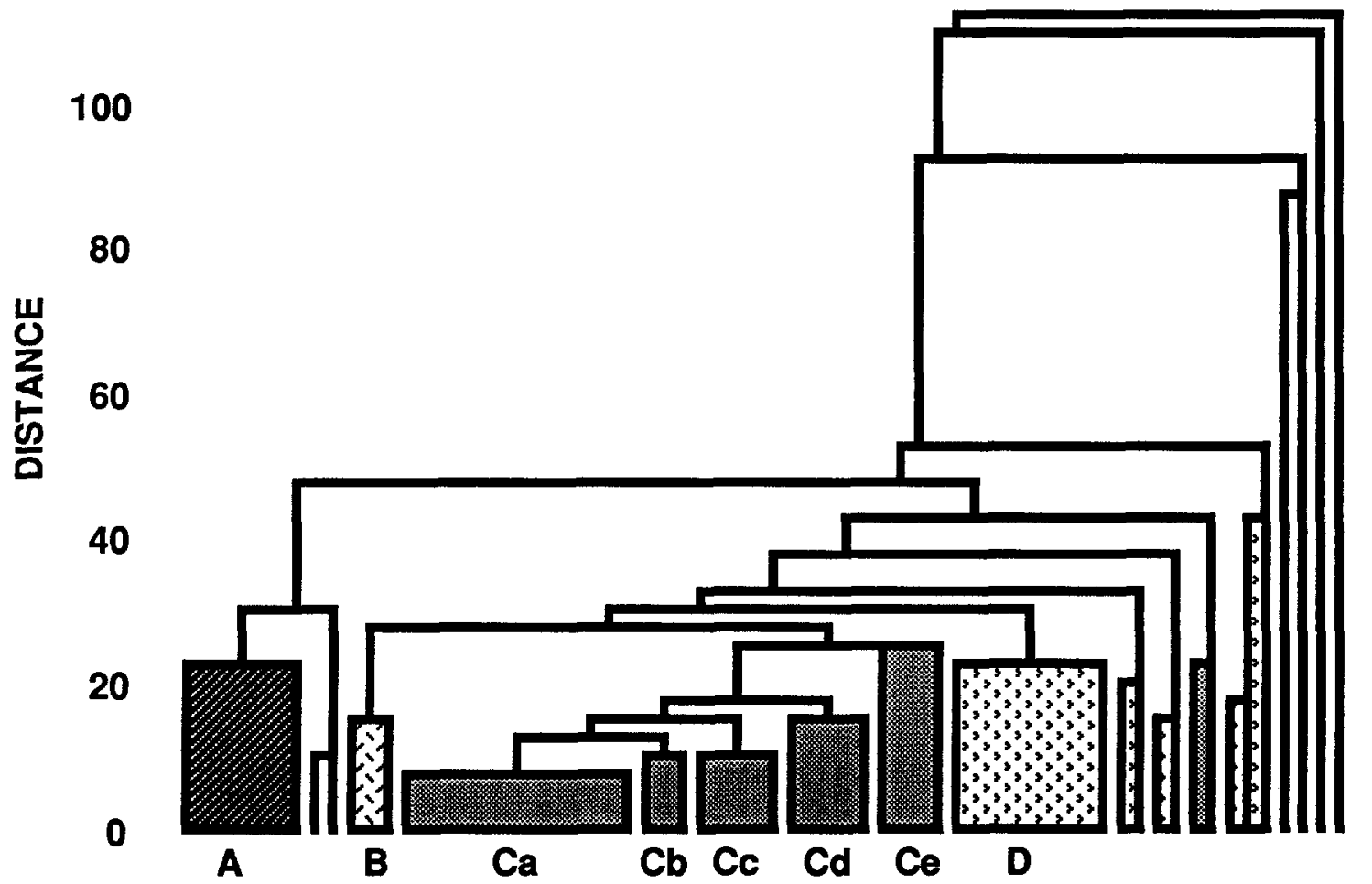

Fig. 11. Cluster analysis based on relative abundance of major diatom taxonomic groups (Table 2) in Lower Herring Lake sediments.

as a result of resuspension and deposition of coarse vegetative material from the littoral zone (Digerfeldt, $1986,1988)$ and during low-lake periods when productivity is greater. Biogenic silica concentrations provide general information on diatom and chrysophyte deposition and infer siliceous algal productivity. The following general model was developed to define longterm signals identified from the sediment.

Falling lake levels are visible in the grain-size data as increased sand or coarse-silt concentrations, as sediments are transported from nearshore areas. A large decrease in $\phi_{50}$ values occurs, followed by deposition of coarser particles within the fine-grained fraction. Biogenic silica concentrations show a sharp decline as levels fall, most likely caused by dilution from the influx of littoral sediments. These redeposited sediments include coarser mineral and organic matter and many benthic-epiphytic diatom forms (Digerfeldt, 1986, 1988). Microfossil signals during these periods include peaks in benthic diatom species, increases in planktonic species which respond quickly to nutrient enrichment, and increases in carbon fragments and phytoliths.

Prolonged low-lake periods are identified by finer $\phi_{50}$ values in the $<38 \mu \mathrm{m}$ fraction. Overall, however, these sediments are coarser than those present in stable-high periods. Sand, organic matter, and carbonate concentrations also increase during low-lake stands. Microfossil signals include increases in phytoliths and a general absence or low abundance of summer planktonic diatoms.

As lake levels rise, an initial influx of coarser sediments occurs in the fine-grained fraction. Increases in biogenic silica and organic matter occur as the sediment limit is again eroded. Sand and carbonate concentrations decline as lake volume increases. Peaks in benthic and epiphytic diatoms, carbon fragments and phytoliths, and increases in summer planktonic diatom species occur as signals in the microfossil assemblages.

Prolonged high levels are indicated by finer $\phi_{50}$ values, increased wt\% biogenic silica, lower sand and 


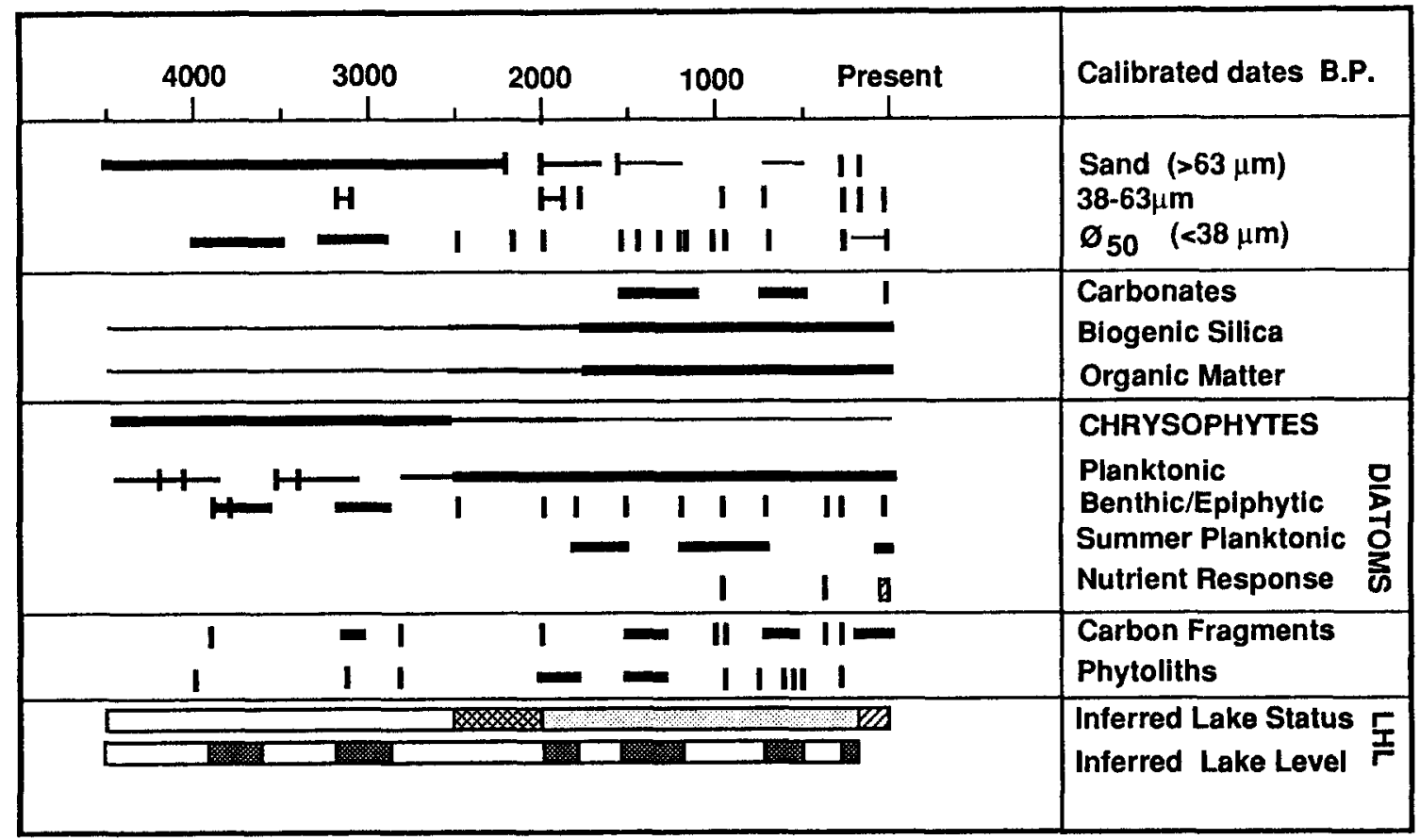

Fig. 12. Summary diagram of paleolimnological results from investigation of Lower Herring Lake sediments. Black lines define signals present in the core. For grain-size data, line thickness represents coarseness of particles present. For chemical and microfossil data, thicker lines indicate greater concentration of a given component in sediments. Vertical bars indicate influxes of material. For lake status designations, white corresponds to pre-isolation, crosshatched area to lake isolation, shaded region indicates post-isolation and diagonal lines define post-settlement. Periods of increasing or high-water levels are indicated by white, periods of falling or lower water levels are indicated by shaded areas. Time scale is based on ${ }^{210} \mathrm{~Pb}$ and ${ }^{14} \mathrm{C}$ dates.

carbonate concentrations, and generally lower organic content. In the microfossil record, higher percentages of summer blooming diatom taxa prevail, particularly those associated with stable thermocline conditions.

Several short-lived events are marked by abrupt stratigraphic changes. These occur during the stablehigh periods and are indicated by increases in the coarse-silt fraction (38-63 $\mu \mathrm{m})$, decreases in the $\phi_{50}$ value of fine-grained sediments, declines in biogenic silica content, and peaks in organic matter which decline rapidly. Microfossils exhibit peaks in benthic and epiphytic diatom taxa, peaks in species which respond rapidly to nutrient influxes, and increases in carbon fragments and phytolith abundance (Wolin, 1992).

\section{Pre-isolation}

\section{Sediment characteristics}

This period represents pre-isolation conditions when Lower Herring Lake was an embayment of the Lake Michigan basin (c. 4300-2600 BP). During this time, the core site existed in a transitional region between depositional and non-depositional zones. Low concentrations of organic matter, biogenic silica, and the absence of coarser particles in the fine-grained fraction, coupled with higher concentrations of sand and carbonates, are consistent with sediments characteristic of transitional zones (Håkanson \& Jansson, 1983). Sedimentation at this site would have been influenced by turbidity currents and erosion of existing sediments from wave action. The result would have been uneven deposition prior to isolation. This energetic system is also reflected in the sand particles which are much coarser than those found in sediments after isolation.

\section{Microfossils}

Pre-isolation microfossils are dominated by chrysophycean cysts (up to 80\%) and highest percentages of benthic diatoms (Figs. 6 and 7). These assemblages are commonly associated with ultra-oligotrophic environments and characterize the embayment-type conditions in Lower Herring Lake. Such assemblages are present in arctic and alpine lakes, and are common 
in post-glacial lake sediments (Bradbury \& Whiteside, 1980; Haworth, 1972, 1976; Smol, 1983, 1985). These low-nutrient environments are unable to support large planktonic populations of diatoms. The resulting high water clarity allows development of benthic communities which live within a nutrient rich benthic boundary layer (Stevenson \& Stoermer, 1982). Planktonic chrysophytes are also common in such systems because they can capitalize on nutrient influxes during spring and fall runoff and mixing periods. Additionally, the presence of microfossils common to large-lake flora indicate the influence of the Nipissing and Algoma Great Lake stages.

As the Lower Herring Lake embayment became increasingly isolated from the Lake Michigan basin, more nutrients became available in the water column enabling a planktonic flora to become established. This process is reflected in the core (between 275 and $237 \mathrm{~cm}$ ) as percentages of planktonic diatoms (Cyclotella bodanica, Fragilaria crotonensis, Aulacoseira ambigua, and Stephanodiscus niagarae) increase and the importance of chrysophyte and benthic diatom assemblages declines.

Those microfossil assemblages that are associated with high-water levels cluster in region D (Fig. 11) and contain higher percentages of planktonic species than other pre-isolation assemblages. Samples containing higher concentrations of benthic diatom taxa are weakly clustered with those associated with lowwater phases. The occurrence of unique assemblages during lower lake periods has several explanations. Physical processes at work in transitional zones result in uneven sediment deposition and these effects would be greater during low-water stages. Under these conditions, low numbers of microfossils and random erosion of sediments would contribute to increased variability between assemblages. Assemblages at 342 and $317 \mathrm{~cm}$ show this variability and occur individually in the cluster analysis. Both samples contain unique assemblage compositions. Two additional samples (350 and $261 \mathrm{~cm}$ ) from pre-isolation sediments cluster between regions A and B. Dominant taxa include Aulacoseira ambigua, Fragilaria crotonensis, and Stephanodiscus niagarae, and Asterionella formosa is present in concentrations similar to those of more recent sediments. The high relative abundances of these taxa, in particular the presence of Asterionella formosa, is uncommon for this region of the core and more closely associated with recent assemblages. Both of these samples occur at levels where an influx of coarse-grained sediments and carbon fragments point to possible increased nutri- ent and mineral input resulting from fire disturbance and may account for the response seen in such taxa as Fragilaria crotonensis and Asterionella formosa.

\section{Lake-level signals}

Although it is unlikely that sedimentation rates are uniform for this portion of the core, estimates were made to infer timing of pre-isolation water-level changes. Three high-lake and two low-lake periods were identified during the pre-isolation period which lasted c. 4500-2200 BP (Fig. 5). High stages are evident between 390-350 cm (c. 4500-3900 BP), $330-305 \mathrm{~cm}$ (c. $3600-3150 \mathrm{BP}$ ), and $285-242 \mathrm{~cm}$ (c. 2900-2200 BP). These high-water levels resulted in increased fine-sediment deposition at the core site (Fig. 5) and higher percentages of planktonic diatoms (Fig. 7). Following each prolonged high-lake period, an influx of coarser fine-grained sediments signals a decline in lake-level. Additional evidence for these declines is seen in a rapid decrease in importance of planktonic diatom populations. Receding water levels result in a reduction of deep-water populations and an increase in benthic or epiphytic forms. Coarser sediments predominate during low-lake stages between 350 and $330 \mathrm{~cm}(c .3900-3570 \mathrm{BP})$ and $305-285 \mathrm{~cm}$ (c. 3150-2900 BP), and the low percentages of planktonic forms in these regions are consistent with predictions under low-water conditions (Figs. 5 and 7). Additionally, decreases in biogenic silica accumulation result from increased exposure of the core site to erosional forces during lower levels (Fig. 3).

Long-shore sedimentary processes continued sand accumulation along the bay-mouth bar until isolation of Lower Herring Lake occurred. The onset of this is evident between 265 and $242 \mathrm{~cm}$ (c. 2550-2200 BP), during the third high-water period as fine-grained sediments become more coarse (Fig. 5). Increases in planktonic microfossils and a decline in chrysophyte taxa indicate changing aquatic conditions consistent with a transition from a bay-type environment to lagoon-like conditions (Figs. 6 and 7).

A comparison of these findings with regional geological investigations indicates that the first preisolation high stage $(390-350 \mathrm{~cm}$, c. $4500-3900 \mathrm{BP})$ corresponds closely to Nipissing II high-lake phase of Larsen (1985a, b, 1987) and Thompson (1992). Water levels then began a long-term decline in the Lake Michigan basin until reaching a lower but stable Algoma high stage (Larsen, 1985a, b, 1987; Fraser et al., 1990; Thompson, 1992). This period of decline 
agrees with the first low-water signal found in Lower Herring Lake at $350-330 \mathrm{~cm}(c .3900-3570 \mathrm{BP})$ and the second high stage ( $330-305 \mathrm{~cm}, c .3600-3150 \mathrm{BP})$ corresponds to the subsequent Algoma phase. A concurrent rise during this time (c. 3300-3100 BP) has also been reported from the sediment record of Lake Ontario (Flint et al., 1988; McCarthy \& McAndrews, 1988; Dalrymple \& Carey, 1990). The second lowwater signal at $305-285 \mathrm{~cm}$ (c. 3150-2900 BP) corresponds to the post-Algoma low of Larsen (1985a) and Fraser et al. (1990). Following this low period, regional geological information for lake-levels is indistinct. Fraser et al. (1990) indicate a possible increase after 2900 BP while reconstructions by Thompson (1992) suggest a continued decline followed by an increase c. 2300 BP. A lack of contiguous stratigraphic evidence leads to this discrepancy. In Lower Herring Lake, however, increases in fine-grained sediments and planktonic microfossils indicate that a third high-water stage existed c. $2900-2200(285-242 \mathrm{~cm})$.

Although lake-level changes prior to isolation of Lower Herring Lake were heavily influenced by glacial-tectonic forces (Nipissing and Algoma levels; Dorr \& Eschman, 1970), evidence for climatic controls can be found in paleoreconstructions. Tree-ring and pollen data from northern North America (Diaz et al., 1989) indicate moist conditions prevailed during high-lake stages with drier conditions more predominant during low-lake periods.

\section{Isolation}

\section{Sediment characteristics}

Isolation of the Lower Herring Lake basin from Lake Michigan occurred sometime between 2500 and 2000 years BP. Onset of this process is marked by an initial decline in $\phi_{50}$ value $(c .265 \mathrm{~cm})$ and increases in biogenic silica (Figs. 5 and 3, respectively). Additionally, lower sand concentration and less variable carbonate concentrations above this level show a decline in minerogenic inputs. The isolation process did not occur in a single event, however, and most likely was a series of partial isolations followed by reinvasion of Lake Michigan waters. During isolation, lagoon-like conditions existed in the embayment that were conducive to greater diatom and chrysophyte production. This is reflected by increased autochthonous sediment deposition and decreased sediment loss from erosional processes.
Increases in sand deposition during final formation of the baymouth bar are seen in the decrease of median phi $\left(\phi_{50}\right)$ size and a sharp influx of sand between 235 and $245 \mathrm{~cm}$. This increase in coarse sediment deposition implies the presence of a higher energy environment. Primary formation of the bar occurred from the north end of the lake toward the south and, as the core site is situated at the south end of the lake, it would have been influenced by the waters of Lake Michigan for a longer period of time. However, as final formation of the bar took place, large amounts of sand were deposited.

A second increase in coarser fine-grained sediments and sand particles at $235 \mathrm{~cm}$ suggests a combined signal of isolation and lake-level decline. The increased percentage of organic matter, and the higher concentration of carbonates (Fig. 3) probably indicate an influx of eroded littoral material along with increased autochthonous deposition. However, nutrient conditions remain ultra-oligotrophic during the transition from an embayment to a lake environment and organic deposition remains low.

\section{Microfossils}

Microfossils indicate that processes leading to lake isolation began $c .270 \mathrm{~cm}$. A decline in importance of chrysophytes occurs (Fig. 6) and planktonic diatom species begin to increase, becoming dominant above $237 \mathrm{~cm}$ (Fig. 7). The final stages of isolation occur c. $237 \mathrm{~cm}$ with a decline in percentages of benthicepiphytic species, and further stabilization of the barrier bar continues until c. $215 \mathrm{~cm}$. Microfossil assemblages resemble lake rather than bay-type flora, reflecting the predominantly lagoon-like conditions. Assemblages in this portion of the core cluster in region $\mathrm{C}$ which also includes the post-isolation flora. Those most characteristic of lagoon-like conditions (c. 265$245 \mathrm{~cm}$ ) are found in clusters $\mathrm{C}_{b}$ and $\mathrm{C}_{e}$ (Fig. 11) while the assemblages present during final isolation and stabilization processes $(c .237-215 \mathrm{~cm})$ are present in cluster $\mathrm{C}_{a}$. This latter cluster also includes assemblages from the post-isolation flora that correspond to periods of transitional or low-lake levels.

Diatom habitat group profiles also show signals related to the isolation process. The increase in benthicepiphytic taxa beginning c. $255 \mathrm{~cm}$ (Fig. 7) probably reflects greater macrophyte distribution and benthic algal production as protection of the shoreline region increases during baymouth bar formation. Relative abundances of planktonic species (Cyclotella stellig- 
era, Fragilaria crotonensis, Aulacoseira ambigua, and Stephanodiscus species) also increase between 255 and $240 \mathrm{~cm}$, probably as a response to increased nutrients and stabilization of the water column (Figs. 8-10).

A dramatic shift in microfossils occurs between 245 and $235 \mathrm{~cm}$, when the lake underwent final isolation. As in the grain-size data, two signals are combined in this level of the core. The first is that of lake isolation, and second is a shift to lower lake levels. Lake isolation is indicated by a decrease in importance of chrysophytes and benthic-epiphytic diatoms, which remain low throughout the remainder of the core. Relative abundances of Aulacoseira ambigua increase to c. $80 \%$ above $235 \mathrm{~cm}$ and this species remains the dominant microfossil until the post-settlement period (Fig. 9). Although the relative abundance of Stephanodiscus niagarae and other Stephanodiscus species decline due to an increase in importance of Aulacoseira ambigua, their total abundance increases after isolation (Fig. 10). As Lower Herring Lake develops into an enclosed basin, an increase in relative abundances of other planktonic species such as Cyclotella spp. and Fragilaria crotonensis also occurs (245$235 \mathrm{~cm}$, Figs. 8 and 9). Above $235 \mathrm{~cm}$, the decline in importance of certain planktonic species (i.e. Cyclotella michiganiana, planktonic Fragilaria, Stephanodiscus alpinus, S. cf. medius; Figs. 8-10) suggests a fall in lake level during the final stages of isolation.

\section{Lake-level signals}

Although sedimentary signals of final isolation are very strong, there are indications of a low-lake period between 235 and $215 \mathrm{~cm}$ (2000-1800 BP). The increase in sand content, influx of carbon fragments and greater numbers of phytoliths imply that increased vegetation and drier conditions prevailed at this time. Such conditions combined with the decrease in importance of planktonic microfossils during a period when one would expect an increase, strongly suggest a decline in lake-level.

A similar decline has also been identified in the beach-ridge deposit record. Thompson $(1992,1993)$ found stratigraphic evidence in southern Lake Michigan for a continued decline between 2300 and c. $1700 \mathrm{BP}$. It appears that climatic effects at this time were widespread as a corresponding low stage has been reported in Lake Ontario between 2300 and $1900 \mathrm{BP}$ (Dalrymple \& Carey, 1990).

\section{Post-isolation/Pre-settlement}

\section{Sediment characteristics}

Following isolation, the core site is located in a deep basin of Lower Herring Lake and this change in depositional environment is clearly reflected in the sedimentary components. The $<38 \mu \mathrm{m}$ silt/clay fraction comprises the majority of these sediments $(>75 \%)$, and a high percentage of this in the clay-size $(<2 \mu \mathrm{m})$ range (Fig. 4). Sand content declines and is characterized by very fine-grained particles and increases in biogenic silica and organic content reflect probable increased production within the lake. The paleorecord for this portion of the core indicates Lower Herring Lake has been a predominantly oligo-mesotrophic lake for much of its history.

\section{Microfossils}

After isolation, microfossil flora are dominated by planktonic assemblages. Changing lake-levels are recorded by brief incursions of benthic and benthicepiphytic taxa, particularly Fragilaria species. This signal of increased Fragilaria species associated with lake-level change has also been seen in Swedish lakes (H. Håkansson, pers. com.). Unfortunately, the signal does not indicate the direction of lake-level change. Possible evidence for falling lake levels can be found in the increasing relative abundances of Cyclotella stelligera and Stephanodiscus cf. medius. Cyclotella stelligera is common in oligo-mesotrophic regions of the Great Lakes area and has been shown to respond quickly to increases in phosphorus (P) (Schelske et al., 1972, 1974, 1975; Schelske \& Stoermer, 1972). Erosion of sediments and decaying littoral vegetation exposed by falling lake levels could provide such nutrient input. Additionally, increased $\mathrm{P}$ loadings resulting from fire during drier climatic conditions cannot be ruled out. Relative abundances of $C$. stelligera are low in this region of the core, but increases occur at 237, 184, and $95 \mathrm{~cm}$, corresponding to periods believed to represent falling lake level. Additional increases of this taxon $c .125$ and $60 \mathrm{~cm}$ reflect basin disturbances which appear to be related to climatic anomalies.

There is some taxonomic uncertainty concerning populations designated Stephanodiscus cf. medius. Characteristics of Lower Herring Lake populations appear to fit somewhere between Stephanodiscus cf. medius (Håkansson \& Kling, 1990: Figs. 34 and 35) and Stephanodiscus alpinus. This taxon is predominantly found in the post-isolation/pre-settlement and 
early post-settlement section of the core and, based on this distribution, appears to have oligotrophic requirements. Increases in both absolute and relative abundance data occur at the same levels as Cyclotella stelligera $(237,180,125,95,60$, and $50 \mathrm{~cm})$ and imply a similar response to nutrient influx.

Another lake-level signal is discernible from the distribution of certain planktonic forms. Cyclotella kuetzingiana, C. michiganiana and Fragilaria crotonensis are common summer plankton in the Great Lakes (Stoermer \& Yang, 1970) found at temperatures c. $15-20{ }^{\circ} \mathrm{C}$ (Stoermer \& Ladewski, 1976) and are frequently found as components of the deep chlorophyll layer (Fahnenstiel \& Glime, 1983; Fahnenstiel \& Scavia, 1987; Stoermer \& Kreis, 1980). During high-water periods, conditions for greater thermocline stability would exist in Lower Herring Lake and facilitate development of a deep chlorophyll layer. Under low-water conditions, stabilization of the thermocline for prolonged periods would be less likely. Low relative abundances of Cyclotella kuetzingiana, C. michiganiana, and Fragilaria crotonensis between 237 and $215 \mathrm{~cm}$ suggest a lack of deep chlorophyll layer development and reduced water levels (Figs. 8 and 9).

The decline in percentages of Stephanodiscus alpinus and $S$. cf. medius may also be related to lower water levels (Fig. 10). Pilskaln \& Johnson (1991) reported higher relative abundance of Stephanodiscus species in Lake Malawi sediments during the rainy season when wind velocity was generally lower. Alternately, dry, windy seasons were dominated by Aulacoseira species. In Lower Herring Lake, cool-wet conditions conducive to higher lake levels would result in longer ice cover and less wind exposure during spring and fall. The Stephanodiscus species present are oligostenothermal forms which predominantly bloom in late winter and early spring. During these periods, Stephanodiscus species would be favored over Aulacoseira ambigua. The latter taxon appears to have optimum growth under warmer temperatures and becomes dominant in Lower Herring Lake during fall mixing (Wolin, unpublished data) when it makes use of increased turbulence to maintain its position in the water column. At highwater levels, susceptibility of the lake to mixing during turbulent weather conditions would diminish. Conversely, low-lake stages, particularly under warm-dry conditions, would result in less ice cover and more frequent periods of turbulence, favoring Aulacoseira ambigua.

General ecological conditions in Lower Herring Lake can also be interpreted from the presence of
Aulacoseira ambigua as a dominant component of the planktonic community. Fritz et al. (1993) report total phosphorus optima of $13.7 \mu \mathrm{g}^{-1}$ for this species based on samples from forty-one northern Michigan lakes. It is a common species in African rift lakes where turbulent conditions prevail, and is reported to have high silica requirements (Kilham et al., 1986; Pilskaln \& Johnson, 1991). Aulacoseira ambigua is also widely reported from temperate lakes of Europe and North America (Bradbury, 1975, 1988; Håkansson, 1989), although temperate forms may prove to be different taxonomic entities than those found in Africa. Stephanodiscus niagarae is also common in the sediments. This species can adapt to changes in nutrient enrichment but does not appear to tolerate hypereutrophic environments (Theriot \& Stoermer, 1984; Stoermer et al., 1989). It commonly blooms in late fall, winter, or early spring at optimum temperatures of $3-6^{\circ} \mathrm{C}$ (Stoermer \& Ladewski, 1976). The high relative abundances of Aulacoseira ambigua and Stephanodiscus niagarae in the sediments indicate that turbulent conditions have been predominant in Lower Herring Lake. Such conditions maintained these taxa in the water column and provided abundant nutrients through resuspension.

\section{Lake-level signals}

During the post-isolation period, three high-lake stages and three low-lake stages were identified (Fig. 13). These long-term shifts between high and low-lake levels exhibit a periodicity of $c$. 500-600 years. Additional fluctuations which occur on the order of $c .150$ years are present and correspond closely to grain-size changes in Lower Herring Lake sediments within these longterm high or low-lake stages. A more detailed discussion of these medium-term fluctuations can be found in Wolin (1992).

The first high-lake period $\left(\mathrm{H}_{A}\right)$ is identified between 215 and $185 \mathrm{~cm}$ (1800-1530 BP) (Fig. 13). The sand component is higher at the onset of this period $\left(\mathrm{H}_{A}-1\right)$, probably due to the lingering effects of basin stabilization and dune formation following isolation. Sand content then decreases once the baymouthbar region becomes stabilized. After an initial influx of coarser grained sediments, fine-grained sediments increase as predicted for high-lake stages $\left(\mathrm{H}_{A}-2\right)$. An influx of benthic microfossils also signals the onset of rising lake-levels (Fig. 7). During this period, increased percentages of taxa associated with the deep chlorophyll layer (Cyclotella kuetzingiana, C. michiganiana, and Fragilaria crotonensis, Figs. 8 and 9) indicate that 


\section{Post-Isolation / Pre-Settlement}
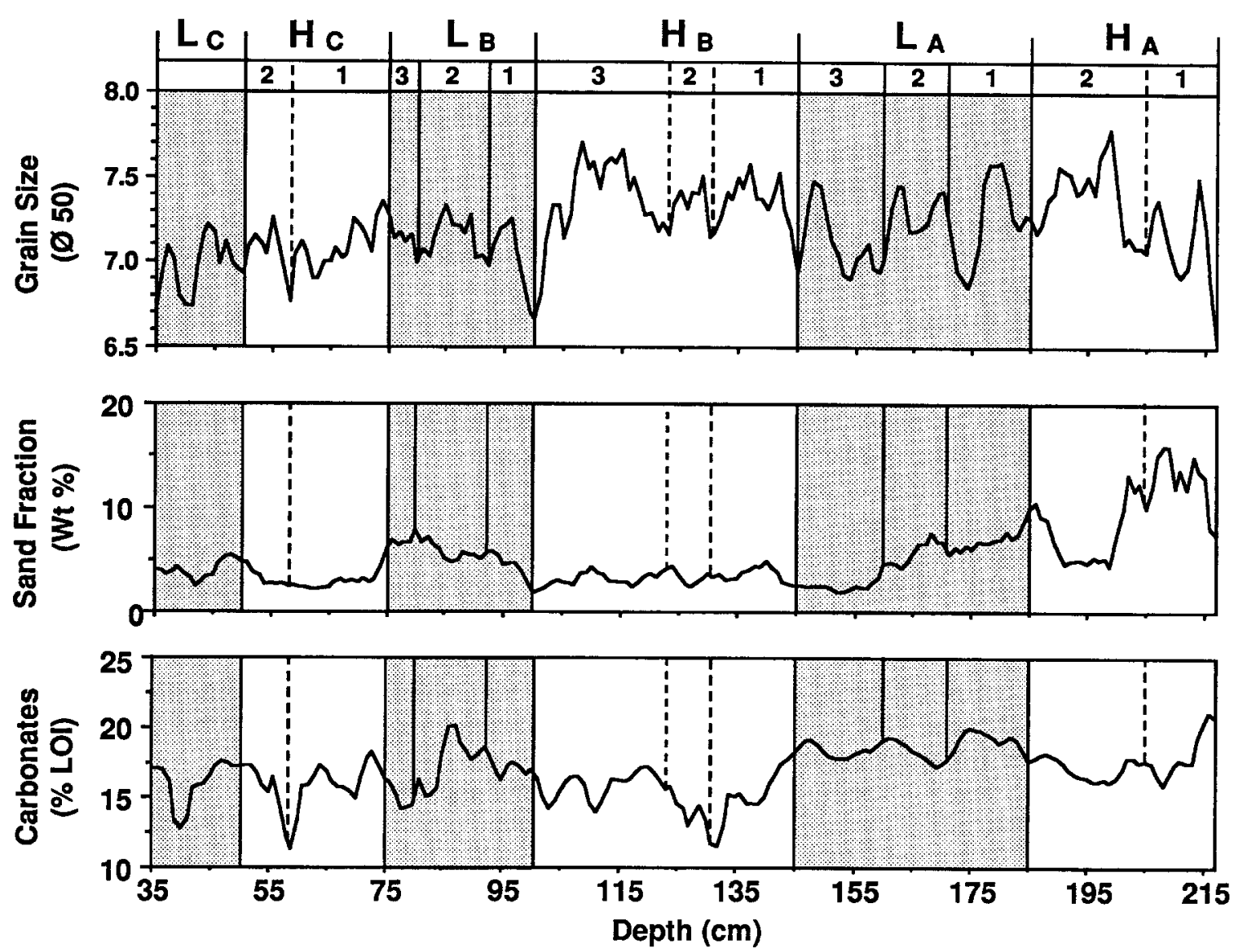

Fig. 13. Grain-size distributions, sand and carbonate concentrations of post-isolation/pre-settlement period. Regions correspond to those of the text. Shaded areas correspond to low-lake levels, unshaded areas correspond to high-lake periods.

stable thermocline conditions associated with highwater levels were probably common.

Regional paleoclimatic reconstructions (Swain, 1978; Bernabo, 1981) indicate generally mild and moist conditions favorable to higher lake levels. The transition seen in Lower Herring Lake between $\mathrm{H}_{A^{-}}$ 1 and $\mathrm{H}_{A}-2$ (c. $1670 \mathrm{BP}$ ) corresponds to a high-level foreshore deposit (1700 cal BP) identified by Thompson (1992) and may represent a maximum rise in lake level during this high-water period. Larsen $(1985 \mathrm{a}, \mathrm{b})$ also found evidence of high levels between 1750 and $1350 \mathrm{BP}$. This high-water period was not only confined to the Lake Michigan basin as high levels have also been reported for Lake Ontario (1900-1500 BP, Dalrymple \& Carey, 1990; and 2100-1500 BP, Flint et al., 1988).
A fall in lake level is recorded in Lower Herring Lake sediments between 1500 and $1170 \mathrm{BP}\left(\mathrm{L}_{A}, 184\right.$ $147 \mathrm{~cm}$ ). This decline is signaled by an increase in the sand fraction, influx of coarser fine-grained sediments, carbon fragments, phytoliths, and benthic-epiphytic microfossils. Sedimentary sand and carbonate content also increase during this period. The low relative abundance of deep chlorophyll microfossils, most likely indicates an overall decline in thermocline stability. An influx of coarser sediments and increase in sand content at region $\mathrm{L}_{A}-2$ (1430-1300 BP) may signal an additional lake-level decline.

Paleoclimate reconstructions indicate cool and dry conditions were predominant in northern North America between 1600-1400 BP (Diaz et al., 1989) and regional studies place this change sometime after 
1500 BP (Swain, 1978; Bernabo, 1981). Such conditions probably initiated the fall to low-water levels found in Lower Herring Lake. Additionally, a sharp decline in paleoprecipation and increase in paleotemperature occurs between 1400 and 1350 BP (Diaz et al., 1989). This change from cool-dry to warm-dry conditions during a low-water phase may well have resulted in the additional signal of decline present in region $\mathrm{L}_{A}-2$. Beach ridge deposits from southern Lake Michigan (Larsen, 1985a, b) indicate declining levels c. $1500 \mathrm{BP}$ and the presence of an extreme low stage at least $0.5 \mathrm{~m}$ below the historical record low of $175.5 \mathrm{~m}$ asl (c. AD 1964). A preliminary report supplied to the author by Thompson (1993) also shows evidence of declining levels after $1500 \mathrm{BP}$ in the Platte Lake embayment located just north of Lower Herring Lake.

A second high-lake stage $\left(\mathrm{H}_{B}\right)$ is identified in sediments between 1170 and $730 \mathrm{BP}(147-100 \mathrm{~cm})$. As seen in previous transitions, an initial influx of coarser fine-grained sediments and of benthic-epiphytic taxa signal a change in lake level. During this high-water stage, the amount of sand and carbonate deposition declines and there is a general increase in fine-grained sediments over previous levels. An increase in planktonic components of the deep chlorophyll layer again implies greater thermocline stability.

Regional climatic reconstructions by Swain (1978) and Bernabo (1981) indicate cool-moist conditions prevailed from 1200 to $1000 \mathrm{BP}$. This shift from a previously warm-dry climate should produce a distinctive increase in water level. Fraser et al. (1990) found evidence of a rapid rise in Lake Michigan levels (c. $1165 \mathrm{BP}$ ) and similar high levels have been discovered in Lake Ontario between 1200 and 950 BP (Flint et al., 1988).

Grain-size and microfossil data signal an additional disturbance in Lower Herring Lake during this second high-lake phase $c$. 1030-940 BP. A distinct shift in microfossil assemblages is evident from the cluster analysis (Fig. 11). Prior to this period (140$127 \mathrm{~cm}$ ), assemblages group in cluster $\mathrm{C}_{d}$, however samples between 115 and $105 \mathrm{~cm}$ cluster in $\mathrm{C}_{c}$. Assemblages at $120 \mathrm{~cm}$ occur as a separate cluster, and visual inspection of the core showed a change in appearance at this point. Two possible explanations arise for these signals. A short-term dramatic drop in lake level would cause increases in coarse particles, benthic-epiphytic forms, and carbon and phytolith fragments, as well as providing a nutrient pulse reflected in the response from Cyclotella stelligera and
Stephanodiscus cf. medius. An alternative explanation might be greater fire activity in the Herring Lakes basin that would also increase carbon fragments and nutrient loadings. Either interpretation suggests the existence of a short-term dry period, similar perhaps to the recent 'dust bowl' years of the 1930s.

Regional climate changed from cool-moist to warm-moist conditions $c .1000$ and continued until 700 BP (Bernabo, 1981; Gajewski, 1988). This corresponds to the stratigraphic change seen in Lower Herring Lake around the same period (1030-940 BP) and coincides with the beginning of the "little climatic optimum' of the Middle Ages (1000-700 BP). While moist conditions were predominant, onset of this warming period may have triggered temporary dry conditions which lead to a short-term decline in lake-level. Evidence of marsh flooding in southern Lake Michigan between 950 and 700 BP (Fraser et al., 1990; Larsen, 1985a) indicates, however, that this short-lived event was followed by a rapid increase in water levels.

A second major decline in lake level is seen in Lower Herring Lake between 730 and $500 \mathrm{BP}\left(\mathrm{L}_{B}\right.$, $100-75 \mathrm{~cm}$ ). As with previous declines, an influx of coarser fine-particle sediments, carbon fragments, phytoliths and benthic-epiphytic microfossils occurs as nearshore sediments are resuspended. Additionally, a decrease in fine-particle size, increases in sand and carbonate deposition, and a decline in deep-chlorophyll layer microfossils occurs during extended low-water conditions. Cool-dry conditions existed in the region between 700 and 500 BP (Bernabo, 1981; Gajews$\mathrm{ki}, 1988$ ) and correspond closely to the low-lake stage identified in Lower Herring Lake. Reconstructions for southern Lake Michigan (Larsen, 1985a, b) also indicate similar timing of a low-water period and lower levels were also present in Lake Ontario from 950 to 400 BP (Flint et al., 1988).

A final high stage is seen between 500 and $280 \mathrm{BP}$ $\left(\mathrm{H}_{C}, 75-50 \mathrm{~cm}\right)$. Although there is no strong influx of coarse material to signal the beginning of this period, decreases in sand content and carbonates do occur (Fig. 13). Additionally, increases in relative abundances of summer planktonic taxa suggest high-water levels. Regional pollen data (Bernabo, 1981; Gajewski, 1988) indicate that cool-moist conditions existed in northern Michigan and Wisconsin between 500$200 \mathrm{BP}$ and a decline in the occurrence of carbon fragments may reflect this change. The increased precipitation would be conducive to higher lake levels. This period (c.500 BP) also corresponds closely to the Little Ice Age, during which, globally cooler temper- 
atures and increased storm conditions were common. Predominantly turbulent conditions could explain the coarser fine-grained sediments and increases in percent organic matter seen in this portion of the core. Geological evidence for a high-water phase also exists in multiple features around the Lake Michigan basin (Fraser et al., 1990; Johnson et al., 1990; Larsen, 1985a, b; Thompson, 1992) and a similar phase (c. 400-200 BP) has been reported from Lake Ontario (Flint et al., 1988).

During this high phase, an additional change is reflected in the paleo-record of Lower Herring Lake between 370 and $325 \mathrm{BP}(c .60 \mathrm{~cm})$. An influx of material from the coarse-silt fraction $(38-63 \mu \mathrm{m})$ and a coarse spike in $\phi_{50}$ data indicate a possible shortlived decline in lake level similar to that seen $c .120 \mathrm{~cm}$. Microfossil evidence suggestive of low-lake levels and drier conditions is present in the increases of benthic Fragilaria species, carbon fragments, and phytoliths. While increases in the relative abundance of Cyclotella stelligera and Stephanodiscus cf. medius imply an influx of nutrients. Such an increase could result from falling lake levels or basin erosion due to increased fire during dry conditions.

Paleoclimatic evidence indicates periods of extreme cold existed between 354 and 258 BP (Diaz et al., 1989). Globally, this period (c. 340-280 BP) has been recognized as an interval of decreased sunspot activity known as the Maunder minimum (Eddy, 1976) and may possibly be linked to climatic responses. Four major air masses converge in the upper Great Lakes region and one or more may influence prevailing weather patterns at a given time (Bryson \& Hare, 1974). If cool-dry arctic air masses were predominant in the Lake Michigan basin, such conditions could initiate a temporary decrease in water level, resulting in the signal seen in Lower Herring Lake sediments. No evidence of this possible lake-level change has been reported from regional shoreline deposits because the presence of most features ends $c$. $500 \mathrm{BP}$. However, records of lower lake levels have been found in subarctic Québec between 360 and 240 BP (Bégin \& Payette, 1988).

A final water-level decline begins at $50 \mathrm{~cm}\left(\mathrm{~L}_{C}\right.$, $280 \mathrm{BP}$ ). Again, an influx of sand, coarser grained sediments, benthic taxa, carbon fragments and phytoliths, imply drier conditions and/or resuspension of nearshore material as lake levels fall. The characteristic decline in summer planktonic taxa associated with stable thermocline conditions and increases in carbonates and coarser fine-grained sediments are also apparent.
Climatic reconstructions for northern Michigan indicate a general warming trend over the past 200 years (Bernabo, 1981) conducive to lower water levels.

As this final decline occurred, it was interrupted by a deforestation signal (c. 1845). By implication, water levels recorded since $1863 \mathrm{AD}$ correspond to a long-term low-water period. Consequently, long-term means or averages calculated from $1900 \mathrm{AD}$ to the present are based on lower water levels than would be present during a high-lake stage and could be as much as $0.5 \mathrm{~m}$ below a $2000-3000$ year average.

\section{Post-settlement}

\section{Sediment characteristics}

Sediment deposition during the post-settlement period is influenced by a variety of factors. Anthropogenic effects of deforestation, agriculture, and nutrient enrichment via wastes and phosphorus detergents result in increased deposition (Engstrom et al., 1985; Schelske, 1991; Schelske et al., 1986; Stoermer et al., 1985, 1990). A deforestation signal in the Herring Lake basin is recorded as a temporary influx of coarsegrained sediments $(35-34 \mathrm{~cm})$. Increases in sand concentrations, coarser $\phi_{50}$ values, and a peak in the 38-63 $\mu \mathrm{m}$ fraction, point to a major basin disturbance (Figs. 4 and 5). Historical information indicates deforestation and anthropogenic influences began c. AD 1845 (Glarum, 1983). Additionally, $\phi_{50}$ values are generally finer in the post-settlement section (Fig. 5) a direct reflection of settlement and agricultural activities within the basin (Warwick, 1980).

\section{Microfossils}

Microfossil assemblages for the post-settlement portion of the core cluster in regions B $(20-30 \mathrm{~cm})$ and A $(16-0 \mathrm{~cm})$. Region $B$ represents changes in phytoplankton which occurred since deforestation (AD 1880-1930) and region A contains modern assemblages reflecting anthropogenic effects of increased settlement and nutrient enrichment (AD 1930-1989). Early influences of settlement appeared to be minor. An increase in relative abundance of planktonic Fragilaria species occurs and $F$. capucina, a more eurytopiceutrophic taxon, represents a larger portion of the assemblage (Fig. 9). More recent impacts from anthropogenic sources have greatly altered the diatom assemblages present in the lake. Although still represented by mesotrophic assemblages, microfossil data indicate a shift in dominant summer flora has occurred since 
c. 1940's. Increases in total microfossil abundance imply greater siliceous algal production as nutrient inputs increased and large increases in the Cyclotella comensis complex have replaced other Cyclotella species formerly occupying this niche (Fig. 8). In general, the oligo-mesotrophic summer flora has been replaced by increased concentrations of eurytopic forms and species associated with increased nitrogen concentrations (i.e. Cyclotella comensis and Fragilaria capucina).

\section{Lake-level signals}

Sedimentary and microfossil signals of the postsettlement record (above $36 \mathrm{~cm}$ ) are dominated by anthropogenic influences. However, some indications of lake-level change are present. The strongest signal is that of known low-water levels during the dust bowl years of the 1930's $(c .20 \mathrm{~cm})$. Similar to lowlake level signals seen in earlier sediments, there is an increase in coarser grained sediments and relative abundance of benthic-epiphytic microfossils between 20-16 cm (A.D. 1929-1944). A weak signal of recent water-level increases may also be present between 8 $5 \mathrm{~cm}$ (c. 1972-1980) with increases in fine-grained sediments. However, it is hard to separate this signal from that of nutrient enrichment effects and problems associated with interpreting information from surficial sediments.

\section{Implications}

Recent high levels experienced in the Great Lakes may be the beginning of a return to long-term higher lake levels. Results from Lower Herring Lake sediments suggest that long-term changes in lake levels occur on the order of 250 to 300 years (500-600 year periodicity). Indications are that the preceding change to lower lake levels occurred approximately 280 years ago and that an increase may occur in the near future. However, these are predictions based on natural climatic fluctuations and do not take into account the effects of increased $\mathrm{CO}_{2}$ and presumed global warming trends.

If the Great Lakes are moving into another highlake cycle, the effects of increased atmospheric $\mathrm{CO}_{2}$ and global warming on lake levels may be muted.Models need to take into account changing conditions based on long-term increases or decreases in lake level. Currently these models use long-term averages based on recorded data. Given that these models are based on lower average lake levels than the long-term data pre- sented here suggest, predictions from these models will indicate stronger effects than should actually be seen. When the Great Lakes again enter a long-term low phase, however, impact on the region should be even greater than predicted. Indeed, Larsen's findings (1985a, b) indicate that the Great Lakes have experienced low-lake levels of a much greater magnitude than any of those present in modern recorded data.

Perhaps one of the most striking points to be made is the strength and predominance of long-term signals in the Lake Michigan basin. Signals which exert themselves in multiple ways ranging from marginal lake processes, to beach ridge and foreshore deposits. A close correlation exists between the findings of Larsen (1985a, b), Fraser et al. (1990) and Thompson (1992) using beach ridge and foreshore deposits of southern Lake Michigan, and in the continuous sedimentary record from Lower Herring Lake located in the northern portion of the basin. Even in the absence of tighter chronological controls, estimates from Lower Herring Lake are well within time periods found by other investigators, an indication that these fluctuations are very strong. Given the strength of these signals, it can be extrapolated that similar evidence should be present in and around each of the Great Lakes and provide a good record of climatic fluctuations across the basin for future investigations.

\section{Acknowledgments}

Funding for this project was provided by a University of Michigan, Rackham Pre-Doctoral Fellowship and by Michigan Sea Grant College Program Grant \#NA89AA-D-SG083. My thanks to E. F. Stoermer for his expertise, comments and review of the manuscript. J. Barres, M. Edlund, D. Francis, R. Hall, T. Johengen, C. Ritter, S. Shoemaker and E. F. Stoermer all provided coring assistance at various times. C. L. Schelske graciously provided ${ }^{210} \mathrm{~Pb}$ dates and $\mathrm{D}$. Rea made coulter counter equipment available. Land use history and additional limnological information was provided by S. Glarum, S. Fritz and the Michigan DNR. T. A. Thompson kindly provided additional information on his work. Contribution No. 573, Center for Great Lakes and Aquatic Sciences, University of Michigan. 


\section{References}

Appleby, P. G. \& F. Oldfield, 1983. The assessment of ${ }^{210} \mathrm{~Pb}$ data from sites with varying sediment accumulation rates. Hydrobiologia 103: 29-35.

Appleby, P. G., P. J. Nolan, D. W. Gifford, M. J. Godfrey, F. Oldfield, N. J. Anderson \& R. W. Battarbee, $1986 .{ }^{210} \mathrm{~Pb}$ dating by low background gamma counting. Hydrobiologia 143: 21-27.

Battarbee, R. W., 1973. A new method for the estimation of absolute microfossil numbers, with reference especially to diatoms. Limnol. Oceanogr. 18: 647-653.

Bégin, Y. \& S. Payette, 1988. Dendroecological evidence of lakelevel changes during the last three centuries in subarctic Québec. Quat. Res. 30: 210-220.

Bernabo, J. C., 1981. Qualitative estimates of temperature changes over the last 2700 years in Michigan based on pollen data. Quat. Res. 15: 143-159.

Bishop, C. T., 1990. Historical variation of water levels in Lakes Erie and Michigan-Huron. J. Great Lakes Res. 16: 406-425.

Bradbury, J. P., 1975. Diatom stratigraphy and human settlement in Minnesota. Geol. Soc. Amer., Special Paper 171: 1-74.

Bradbury, J. P., 1988. A climatic-limnologic model of diatom succession for paleolimnological interpretation of varved sediments at Elk Lake, Minnesota. J Paleolimnol. 1: 115-131.

Bradbury, J. P. \& M. W. Whiteside, 1980. Paleolimnology of two lakes in the Klutlan Glacier region, Yukon Territory, Canada. Quat. Res. 14: 149-168.

Bryson, R. A. \& K. K. Hare, 1974. The climatic patterns of North America. In R. A. Bryson \& K. K. Hare (eds.), World Survey of Climatology; v. 11, Climates of North America: 1-47. Elsevier, Amsterdam.

Carney, H. J., 1982. Algal dynamics and trophic interactions in the recent history of Frains Lake, Michigan. Ecology 63: 1814-1826.

Carney, H. J. \& C. D. Sandgren, 1983. Chrysophycean cysts: indicators of eutrophication in recent sediments of Frains Lake, Michigan, USA. Hydrobiologia 101: 195-202.

Dalrymple, R. W. \& J. S. Carey, 1990. Water-level fluctuations in Lake Ontario over the last 4000 years as recorded in the Cataraqui River lagoon, Kingston, Ontario. Can. J. Earth Sci. 27: 13301338.

Davis, C. O. \& M. S. Simmons, 1979. Water chemistry and phytoplankton field and laboratory procedures. University of Michigan, Great Lakes Research Division Special Report 70: 173.

DeMaster, D. J., 1979. The marine budgets of silica and ${ }^{32} \mathrm{Si}$. Ph. D. thesis, Yale University, New Haven, Conn. 308 pp.

DeMaster, D. J., 1981. The supply and accumulation of silica in the marine environment. Geochim. Cosmochim. Acta 45: 17151732.

Dean. W. R., Jr., 1974. Determination of carbonate and organic matter in calcareous sedimentary rocks by loss on ignition: comparison with other methods. J. Sed. Petrol. 44: 242-248.

Dearing, J. A. \& I. D. L. Foster, 1986. Lake sediments and palaeohydrological studies. In B. E. Berglund (ed.), Handbook of Holocene Palaeoecology and Palaeohydrology. John Wiley and Sons, New York: 67-90.

Diaz, H. F., J. T. Andrews \& S. K. Short, 1989. Climate variations in northern North America (6000 BP to present) reconstructed from pollen and tree-ring data. Arctic and Alpine Research 21: 45-59.

Digerfeldt, G., 1986. Studies on past lake-level fluctuations. In B. E. Berglund (ed.), Handbook of Holocene Palaeoecology and Palaeohydrology. John Wiley and Sons, New York: 127-143.
Digerfeldt, G., 1988. Reconstruction and regional correlation of Holocene lake-level fluctuations in Lake Bysjön, south Sweden. Boreas 17: 165-182.

Dorr, J. A., Jr. \& D. F. Eschman, 1970. Geology of Michigan. University of Michigan Press, Ann Arbor: 213-217.

Duff, K. E. \& J. P. Smol, 1988. Chrysophycean stomatocysts from the postglacial sediments of a High Arctic lake. Can. J. Bot. 66: $1117-1128$.

Eddy, J. A., 1976. The Maunder Minimum. Science 192: 1189-1202.

Engstrom, D. R., E. B. Swain \& J. C. Kingston, 1985. A paleolimnological record of human disturbance from Harvey's Lake, Vermont: geochemistry, pigments and diatoms. Freshwat. Biol. 15: $261-288$.

Fahnenstiel, G. L. \& J. M. Glime, 1983. Subsurface chlorophyll maximum and associated Cyclotella pulse in Lake Superior. Int. Revue ges. Hydrobiol. 68: 605-618.

Fahnenstiel, G. L. \& D. Scavia, 1987. Dynamics of Lake Michigan phytoplankton: the deep chlorophyll layer. J. Great Lakes Res. 13: 285-295.

Flint, J. E., R. W. Dalrymple \& J. J. Flint, 1988. Stratigraphy of the Sixteen Mile Creek lagoon, and its implications for Lake Ontario water levels. Can. J. Earth Sci. 25: 1175-1183.

Folk, R. L., 1974. Petrology of Sedimentary Rocks. Hemphill, Austin, Texas, 182 pp.

Fraser, G. S., C. E. Larsen \& N. C. Hester, 1990. Climatic control of lake levels in the Lake Michigan and Lake Huron basins. Geol. Soc. Amer. Spec. Pap. 251: 75-89.

Fritz, S. C., J. C. Kingston \& D. R. Engstrom, 1993. Quantitative trophic reconstruction from sedimentary diatom assemblages: a cautionary tale. Freshwat. Biol. 30: 1-23.

Fox, D. J. \& K. E. Guire, 1980. Documentation for MIDAS. Statistical Research Laboratory, University of Michigan, Ann Arbor, 203 pp.

Gaillard, M.-J., J. A. Dearing, F. El-Daoushy, M. Enell \& H. Håkansson, 1991. A late Holocene record of land-use history, soil erosion, lake trophy, and lake-level fluctuations at Bjäresjösjön (South Sweden). J, Paleolimnol. 6: 51-81.

Gajewski, K., 1988. Late Holocene climate changes in eastern North America estimated from pollen data. Quat. Res. 29: 255-262.

Glarum, S. N., 1983. Our Land and Lakes. Michigan, Benzie County, Lower Herring Lake. West Graf, J.B. Publications. Manistee, Michigan, $70 \mathrm{pp}$

Glover, R. M., 1982. Diatom fragmentation in Grand Traverse Bay, Lake Michigan and its implications for silica cycling. Ph.D. thesis, University of Michigan, Ann Arbor, 204 pp.

Håkanson, L. \& M. Jansson, 1983. Principles of Lake Sedimentology. Springer-Verlag, New York, New York. 316 pp.

Håkansson, H., 1989. Diatom succession during Middle and Late Holocene time in Lake Krageholmssjön, southern Sweden. Nova Hedwigia 48: 143-166.

Håkansson, H. \& H. Kling, 1990. The current status of some very small freshwater diatoms of the genera Stephanodiscus and Cyclostephanos. Diatom Research 5: 273-287.

Haworth, E. Y., 1972. Diatom succession in a core from Pickerel Lake, northeastern South Dakota. Geol. Soc. Amer. Bull. 83: 157-172.

Haworth, E. Y., 1976. Two late-glacial (Late Devensian) diatom assemblage profiles from northern Scotland. New Phytol. 77: 227-256.

Johnson, T. C., R. D. Stieglitz \& A. M. Swain, 1990. Age and paleoclimatic significance of Lake Michigan beach ridges at Baileys Harbor, Wisconsin. Geol. Soc. Amer. Spec. Pap. 251: 67-74. 
Kilham, P., S. S. Kilham \& R. E. Hecky, 1986. Hypothesized resource relationships among African planktonic diatoms. Limnol. Oceanogr. 31: 1169-1181.

Krausse, G. L., C. L. Schelske \& C. O. Davis, 1983. Comparison of three wet-alkaline methods of digestion of biogenic silica in water. Freshwat. Biol. 13: 73-81.

Larsen, C. E., 1985a. A stratigraphic study of beach features on the southwestern shore of Lake Michigan: New evidence of Holocene lake level fluctuations. Illinois State Geological Survey, Environmental Geology Notes 112, 31 pp.

Larsen, C. E., 1985b. Lake level, uplift, and outlet incision, the Nipissing and Algoma Great Lakes. In P. F. Karrow and P. E. Calkin (eds), Quaternary Evolution of the Great Lakes. Geological Association of Canada, Special Paper 30: 63-77.

Larsen, C. E., 1987. Geological history of glacial Lake Algonquin and the upper Great Lakes. U.S. Geological Survey Bulletin 1801, $36 \mathrm{pp}$.

McCarthy, F. M. G. \& J. H. McAndrews, 1988. Water levels in Lake Ontario 4230-2000 years B.P. Evidence from Grenadier Pond, Toronto, Canada. J. Paleolimnol. 1: 99-113.

National Oceanic and Atmospheric Administration (NOAA), 1992. Hydrograph of monthly mean levels of the Great Lakes. U.S. Department of Commerce, NOAA, National Ocean Survey, Washington, D.C.

Nygaard, G., 1956. Ancient and recent flora of diatoms and Chrysophyceae in Lake Gribsø. In K. Berg and J. C. Petersen (eds), Studies on the Humic Acid Lake Gribsø. Folia limnol. scand. 8: 32-93.

Okuda, S., 1984. The influences of human activities on Lake Biwa. In S. Horie (ed.), Lake Biwa, Junk, Dordrecht: 635-641.

Patrick, R. P. \& C. W. Reimer, 1966. The Diatoms of the United States. Vol I. Academy of Natural Sciences, Philadelphia. Monograph No. 13,688 pp.

Pearson, G. W. \& M. Stuiver, 1986. Radiocarbon 28: 839-862.

Pilskaln, C. H. \& T. C. Johnson, 1991. Seasonal signals in Lake Malawi sediments. Limnol. Oceanogr. 36: 544-557.

Richardson, J. L., 1969. Former lake-level fluctuations - their recognition and interpretation. Internationale Vereinigung für Theoretische und Angewandte Limnologie - Mitteilungen 17: 78-93.

Sandgren, C. D. \& H. J. Carney, 1983. A flora of fossil chrysophycean cysts from the recent sediments of Frains Lake, Michigan USA Nova Hedwiga 38: 129-163.

Schelske, C. L., 1991. Historical nutrient enrichment of Lake Ontario; paleolimnological evidence. Can. J. Fish. aquat. Sci. 48: $1529-1538$.

Schelske, C. L. \& E. F. Stoermer, 1972. Phosphorus, silica and eutrophication of Lake Michigan. In G. E. Likens (ed.), Nutrients and Eutrophication. Special Symposia Vol. 1. American Society of Limnol. Oceanogr., Allen Press Lawrence, Kansas: 157-171.

Schelske, C. L., M. S. Simmons \& L. E. Feldt, 1975. Phytoplankton responses to phosphorus and silica enrichment in Lake Michigan. Verh. int. Ver. für Limnol. 19: 911-921.

Schelske, C. L., L. E. Feldt, M. A. Santiago \& E. F. Stoermer, 1972. Nutrient enrichment and its effect on phytoplankton production and species composition in Lake Superior. Proceedings 15th Conference of Great Lakes Research. Int. Assoc. Great Lakes Res.: 149-163.

Schelske, C. L., E. D. Rothman, E. F. Stoermer \& M. A. Santiago, 1974. Responses of phosphorus limited Lake Michigan phytoplankton to factorial enrichments with nitrogen and phosphorus. Limnol. Oceanogr. 19: 409-419.
Schelske, C. L., D. J. Conley, E. F. Stoermer, T. J. Newberry \& C. D. Cambell, 1986. Biogenic silica and phosphorus accumulation in sediments as indices of eutrophication in the Laurentian Great Lakes. Hydrobiologia 143: 79-86.

Smol, J. P., 1983. Paleophycology of a high arctic lake near Cape Herschel, Ellesmere Island. Can. J. Bot. 61: 2195-2204.

Smol, J. P., 1985. The ratio of diatom frustules to chrysophycean statospores: A useful paleolimnological index. Hydrobiologia 123: 199-208.

Smol, J. P., S. R. Brown \& R. N. McNeely, 1983. Cultural disturbances and trophic history of a small meromictic lake from Central Canada. Hydrobiologia 103: 125-130.

Stevenson, R. J. \& E. F. Stoermer, 1982. Luxury consumption of phosphorus by benthic algae. BioScience 32: 682-683.

Stoermer, E. F. \& R. G. Kreis, Jr., 1980. Phytoplankton composition and abundance in southern Lake Huron. USEPA, Office of Research and Development, Duluth, Minnesota, 396 pp.

Stoermer, E. F. \& T. B. Ladewski, 1976. Apparent optimal temperatures for the occurrence of some common phytoplankton species in southern Lake Michigan. Univ. Michigan, Great Lakes Res. Div. Spec. Rep. 18: 48 pp.

Stoermer, E. F. \& J. J. Yang, 1970. Distribution and relative abundance of dominant plankton diatoms in Lake Michigan. University of Michigan, Great Lakes Res. Div. Special Report 16, 64 pp.

Stoermer, E. F., G. Emmert \& C. L. Schelske, 1989. Morphological variation of Stephanodiscus niagarae Ehrenb, (Bacillariophyta) in a Lake Ontario sediment core. J. Paleolimnol. 2: 227-236.

Stoermer, E. F., J. A. Wolin, C. L. Schelske \& D. C. Conley, 1985. An assessment of changes during the recent history of Lake Ontario based on siliceous microfossils preserved in the sediments. $\mathrm{J}$. Phycol. 21: 257-276.

Stoermer, E. F., J. A. Wolin, C. L. Schelske \& D. C. Conley, 1990. Siliceous microfossil succession in Lake Michigan. Limnol. Oceanogr. 35: 959-967.

Swain, A. M., 1978. Environmental changes during the past 2000 years in north central Wisconsin: analysis of pollen, charcoal, and seeds from varved lake sediments. Quat. Res. 10: 55-68.

Theriot, E. C. \& E. F. Stoermer, 1984. Principle component analysis of Stephanodiscus: Observations on two new species from the Stephanodiscus niagarae complex. Bacillaria 7: 37-58.

Thompson, T. A., 1992. Beach-ridge development and lake-level variation in southern Lake Michigan. Sed. Geol. 80: 305-318.

Thompson, T. A., 1993. Preliminary report of late Holocene lakelevel variation in northern Lake Michigan: Part 1. U.S. Geol. Surv., Open File Rep. 93-4: 1-14.

van der Werff, A., 1955. A new method for concentrating and cleaning diatoms and other organisms. Verh. int. Ver. Limnol. 12: 276-277.

Warwick, W. F., 1980. Palaeolimnology of the Bay of Quinte, Lake Ontario: 2800 years of cultural influence. Can. Bull. Fish. aquat. Sci. 206: 117 pp.

Wolin, J. A., 1992. Paleoclimatic implications of late Holocene lakelevel fluctuations in Lower Herring Lake, Michigan. Ph.D. thesis, University of Michigan, Ann Arbor, $155 \mathrm{pp}$.

Wright, H. E., Jr., 1967. A square-rod piston sampler for lake sediments. J. Sed. Petrol. 37: 975-976.

Wright, H. E., Jr., 1991. Coring Tip.s J. Paleolimnol. 6: 37-49.

Yamamoto, A., 1984. Grain size variation. In S. Horie (ed.), Lake Biwa. Junk, Dordrecht: $439-459$. 